January 2003 • NREL/TP-550-33106

\title{
Preliminary Energy Analysis of the Pennsylvania Department of Environmental Protection's Cambria Office Building Ebensburg, PA
}

M. Deru

National Renewable Energy Laboratory

E. Hancock

Mountain Energy Partnership

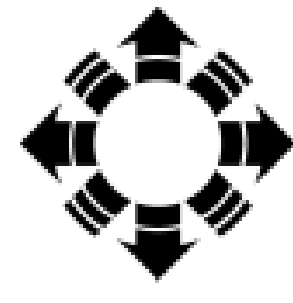

NPEI

National Renewable Energy Laboratory

1617 Cole Boulevard

Golden, Colorado 80401-3393

NREL is a U.S. Department of Energy Laboratory

Operated by Midwest Research Institute $\bullet$ Battelle $\bullet$ Bechtel

Contract No. DE-AC36-99-G010337 


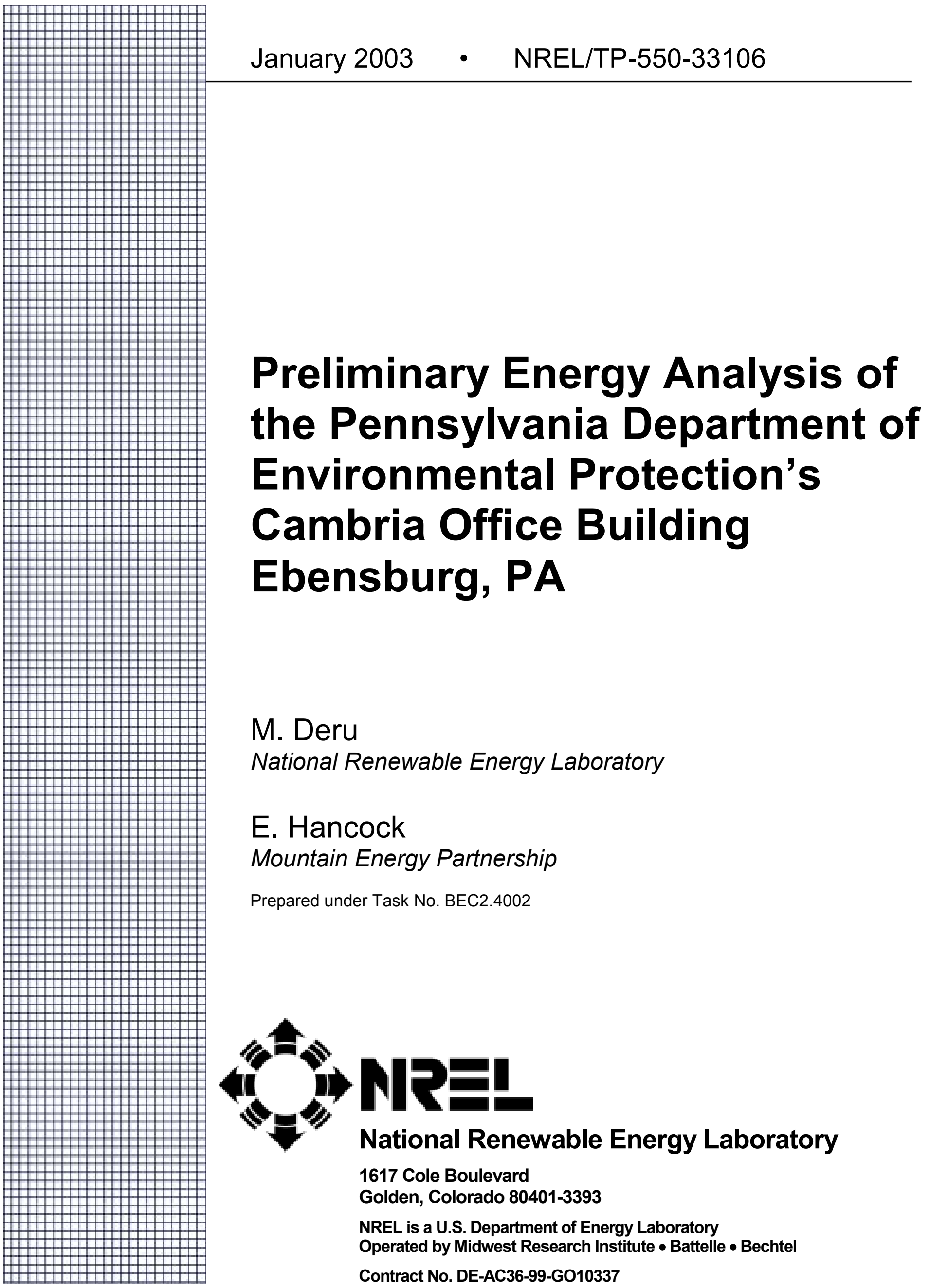




\section{NOTICE}

This report was prepared as an account of work sponsored by an agency of the United States government. Neither the United States government nor any agency thereof, nor any of their employees, makes any warranty, express or implied, or assumes any legal liability or responsibility for the accuracy, completeness, or usefulness of any information, apparatus, product, or process disclosed, or represents that its use would not infringe privately owned rights. Reference herein to any specific commercial product, process, or service by trade name, trademark, manufacturer, or otherwise does not necessarily constitute or imply its endorsement, recommendation, or favoring by the United States government or any agency thereof. The views and opinions of authors expressed herein do not necessarily state or reflect those of the United States government or any agency thereof.

Available electronically at http://www.osti.gov/bridge

Available for a processing fee to U.S. Department of Energy

and its contractors, in paper, from:

U.S. Department of Energy

Office of Scientific and Technical Information

P.O. Box 62

Oak Ridge, TN 37831-0062

phone: 865.576.8401

fax: 865.576.5728

email: reports@adonis.osti.gov

Available for sale to the public, in paper, from:

U.S. Department of Commerce

National Technical Information Service

5285 Port Royal Road

Springfield, VA 22161

phone: 800.553.6847

fax: 703.605.6900

email: orders@ntis.fedworld.gov

online ordering: http://www.ntis.gov/ordering.htm 


\section{Table of Contents}

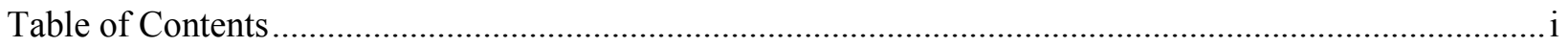

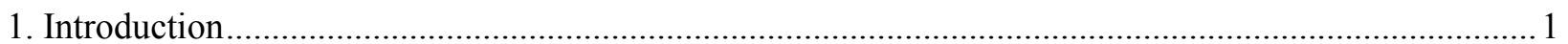

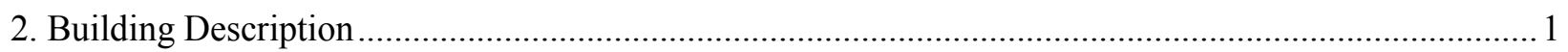

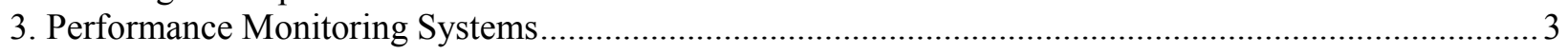

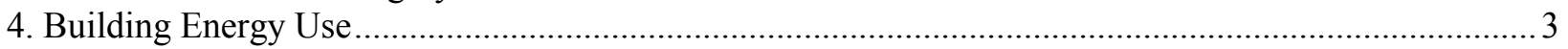

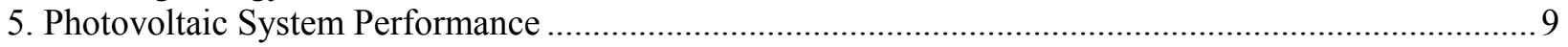

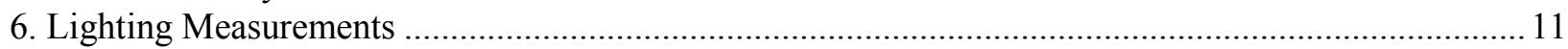

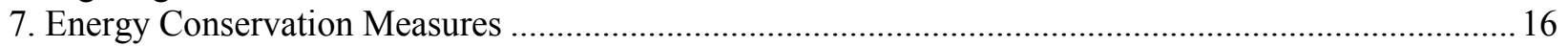

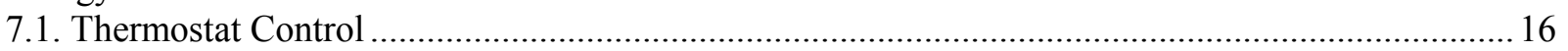

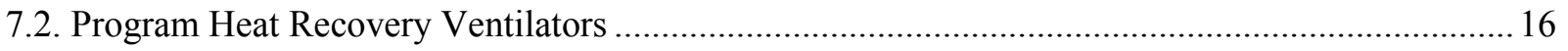

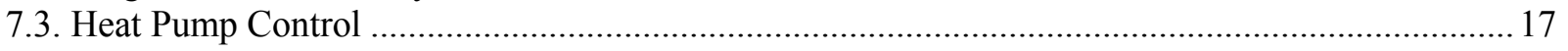

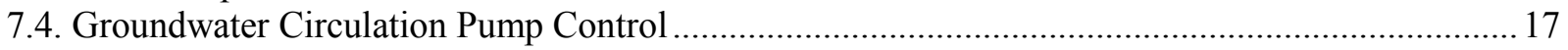

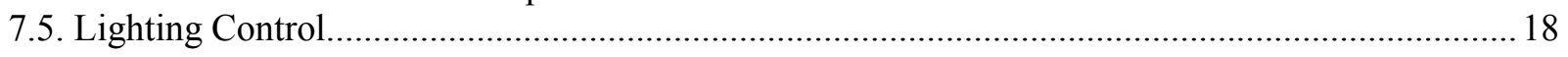

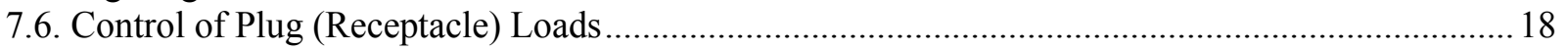

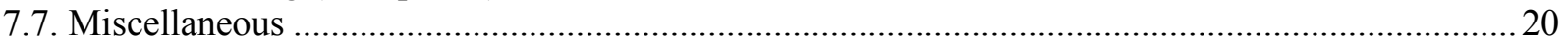

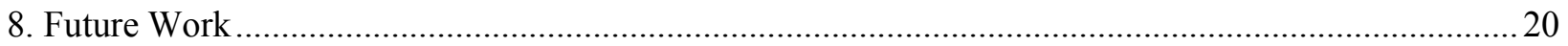

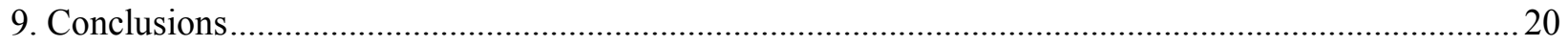

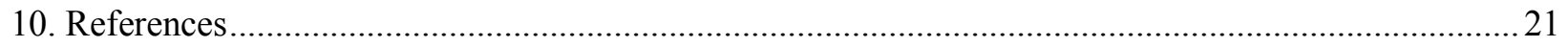




\section{Introduction}

The Pennsylvania Department of Environmental Protection (DEP) has undertaken a path to build "high performance green" buildings as part of the objectives of the Governor's Green Government Council (http://www.gggc.state.pa.us). The first building, completed in 1998, is used as the DEP's regional headquarters in Harrisburg. The Cambria office, located in Ebensburg, is DEP's second building. Many of the lessons learned from the first building were successfully applied to this building, which was completed in 2000 . The objective was to provide a comfortable and productive work environment while minimizing its short- and long-term environmental impacts.

This report covers an energy analysis performed by the High Performance Buildings Research group from the National Renewable Energy Laboratory (NREL) in Golden, Colorado. The study included a detailed review of the energy systems, analysis of the 15-minute power data from July 2001 to February 2002, and review of the utility bills. Daylighting measurements were also conducted during the site visit in July 2001.

\section{Building Description}

Figure 1 shows the main entrance of the Cambria office building. There are $34,500 \mathrm{ft}^{2}\left(3,205 \mathrm{~m}^{2}\right)$ on two floors, as shown in the floor plans in Figure 2. The building contains office space for approximately 100 people, a large file storage area, two small laboratory areas, conference rooms, and general storage areas. The building is oriented on a long east-west axis. The exterior walls are constructed with R-30 $\mathrm{h} \cdot \mathrm{ft}^{2} \cdot{ }^{\circ} \mathrm{F} / \mathrm{Btu}$ insulated concrete forms, the roof has a composite insulating value of $\mathrm{R}-33 \mathrm{~h} \cdot \mathrm{ft}^{2} \cdot{ }^{\circ} \mathrm{F} / \mathrm{Btu}$, and the slab-on-grade floor is insulated with $\mathrm{R}-10 \mathrm{~h} \cdot \mathrm{ft}^{2} \cdot{ }^{\circ} \mathrm{F} / \mathrm{Btu}$ around the perimeter. The manufactured windows have an overall $\mathrm{U}$-value of $0.29 \mathrm{Btu} / \mathrm{h} \cdot \mathrm{ft}^{2} \cdot{ }^{\circ} \mathrm{F}$, and the storefront windows have a U-value of 0.26 $\mathrm{Btu} / \mathrm{h} \cdot \mathrm{ft}^{2} \cdot{ }^{\circ} \mathrm{F}$. Ebensburg is a heating-dominated climate with approximately 6700 heating degree days (base $\left.65^{\circ} \mathrm{F}\left[\mathrm{HDD}\left(18^{\circ} \mathrm{C}\right)=3722\right]\right)$ and 400 cooling degree days (base $65^{\circ} \mathrm{F}\left[\mathrm{CDD}\left(18^{\circ} \mathrm{C}\right)=222\right]$ ).

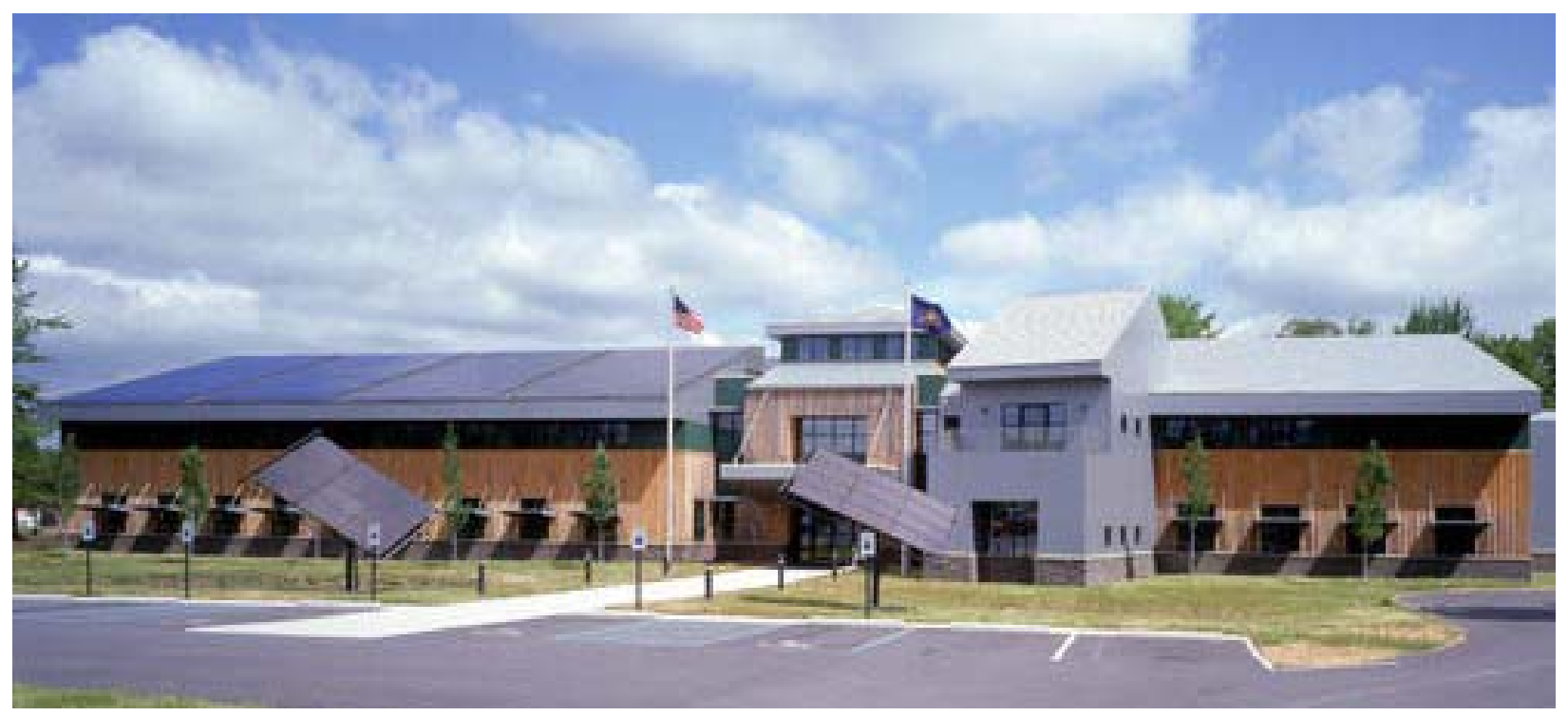

Figure 1. View of the south side of the Pennsylvania DEP Cambria office building 

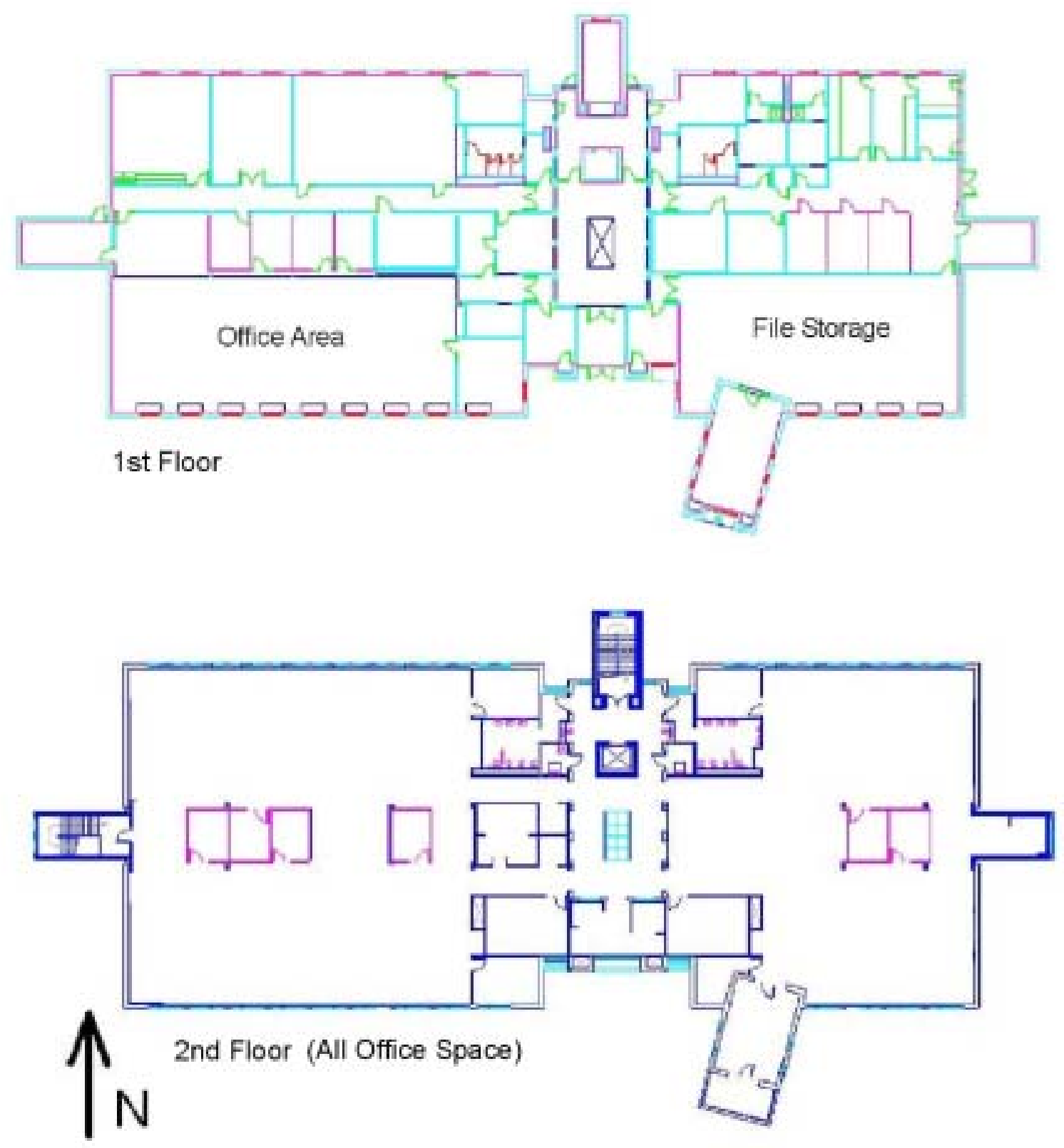

Figure 2. Floor plans of the Cambria office building

All energy systems in the building are electric. Eleven ground-source heat pumps provide the heating and cooling. Two heat-recovery ventilators on the roof provide the ventilation make-up air to the two mechanical rooms, which act as plenums to mix the outside air with the return air. The air is delivered to the spaces via an under-floor air distribution system with floor-mounted diffusers.

The luminaires in the office areas are indirect fixtures that use electronic ballasts and T- 8 fluorescent lamps. They have an installed lighting power density of approximately $0.75 \mathrm{~W} / \mathrm{ft}^{2}$. Two task lights are provided for each workstation to bring the total installed lighting power density to approximately 1.25 $\mathrm{W} / \mathrm{ft}^{2}$. The luminaires in the second floor offices have dimmable ballasts controlled by lighting sensors in 
each office area. Compact fluorescent lamps are used in other areas. The restroom and workstation task lights have occupancy sensors.

Two photovoltaic (PV) systems are installed outside (see Figure 1). The small PV system has 24 43-W amorphous silicon panels (for an approximate total of $1 \mathrm{~kW}$ ) mounted on two tracking units in front of the building. The inverter, a residential-size unit mounted on one of the tracking poles, feeds the power into the first floor east heating, ventilation, and air conditioning (HVAC) electrical panel. The large PV system has $40043-W$ panels (for an approximate total of $17.2 \mathrm{~kW}$ ) mounted at a fixed tilt angle on the southfacing roof. The inverter for this system is a commercial three-phase 15-kW unit mounted on the roof. The power from this system feeds into the main distribution panel and is monitored with a standard utility power meter.

\section{Performance Monitoring Systems}

The building's total electrical energy use is measured by the utility power meter. Another utility meter monitors the large PV system. In addition, a Square D PowerLogic ${ }^{\circledR}$ system monitors the energy use in each of the 10 major electrical panels. This system was set up to record the instantaneous electrical power every 15 minutes. Table 1 shows the electrical panels and the loads monitored by this system. The large PV system is monitored only once a month; therefore, estimating the real time effects on the demand and the total electricity is difficult. The small PV system feeds into the $1^{\text {st }} \mathrm{E}$ Heat Panel and has a small effect on the panel's load.

Table 1. Electrical Panels on the Power Monitoring System

\begin{tabular}{|l|l|}
\hline \multicolumn{1}{|c|}{ Electrical Panel } & \multicolumn{1}{c|}{ Loads } \\
\hline \hline $1^{\text {st }}$ E Heat Panel & heat pumps, circulation pumps, water heater \\
\hline $1^{\text {st }}$ E Light Panel & lights \\
\hline $1^{\text {st }}$ E Rec Panel & telephones, water cooler, freezer, receptacles \\
\hline $1^{\text {st }}$ W Heat Panel & heat pumps, circulation pumps \\
\hline $1^{\text {st }}$ W Light Panel & lights \\
\hline $1^{\text {st }}$ W Rec Panel & receptacles, kitchen loads \\
\hline $2^{\text {nd }}$ Light Panel & lights, water cooler, sprinkler compressor \\
\hline $2^{\text {nd }}$ Rec Panel & receptacles \\
\hline Elevator & elevator \\
\hline EMR Panel & egress lights, exit signs, fire panel \\
\hline
\end{tabular}

There are carbon dioxide $\left(\mathrm{CO}_{2}\right)$ and temperature sensors in each of the four main office areas to monitor indoor air quality. These systems are connected to a data-logging system in the information systems room.

\section{Building Energy Use}

The energy use intensity (EUI), which is the annual energy use per square foot, provides a quick representation of energy performance. Based on the utility bills for 2001, the purchased EUI was 41.9 $\mathrm{kBtu} / \mathrm{ft}^{2} / \mathrm{yr}\left(12.3 \mathrm{kWh} / \mathrm{ft}^{2} / \mathrm{yr}\right)$, or $\$ 0.82 / \mathrm{ft}^{2} / \mathrm{yr}$ in terms of cost. The utility bills include the parking lot lights and the effects of the energy provided by the two PV systems. Based on the measured output of the large PV system over 8 months, the annual production for 2001 was approximately $16 \mathrm{MWh}$. Therefore, the 
EUI of the building based on the used energy is approximately $43 \mathrm{kBtu} / \mathrm{ft}^{2} / \mathrm{yr}\left(12.6 \mathrm{kWh} / \mathrm{ft}^{2} / \mathrm{yr}\right)$. The building has the potential to perform much better with some minor changes (see Section 7).

According to the 1999 Commercial Buildings Energy Consumption Survey (EIA 2002), the average EUI of an office building of similar size and climate would be approximately $80-85 \mathrm{kBtu} / \mathrm{ft}^{2} / \mathrm{yr}(23.5-24.9$ $\mathrm{kWh} / \mathrm{ft}^{2} / \mathrm{yr}$ ). This indicates that the Cambria office building uses about half the energy of typical office buildings in the same region.

The breakdown of energy by end use is shown in Figures 3 and 4 for weekdays and weekends/holidays. These figures show the average daily energy use for the HVAC, lighting, and plug loads for July 2001 through February 2002. The data are based on measurements from the PowerLogic ${ }^{\circledR}$ system, which had periods of missing data in every month except September, November, and February. The missing data are expected to have a small effect on the average values because the energy use patterns are consistent. The weekday energy use (Figure 3) is similar for each month. A small energy-efficient building such as this one should exhibit a significant decrease in the HVAC energy when the internal loads can be met by outside air, such as in the fall and spring months. The weekend/holiday energy use increases in the fall and winter months because (1) there is no setback on the HVAC controls, so the heating load increases when the building is unoccupied in the cold weather; and (2) the weekend/holiday lighting load increases because the lights are programmed to come on every weekday, even when a holiday falls on a weekday. Figure 4 shows that the building energy use is high during unoccupied times and is therefore an area to focus on for energy savings. Overall, the HVAC systems consume approximately $55 \%$ of the total energy, the lights $21 \%$, and the plug loads $24 \%$.

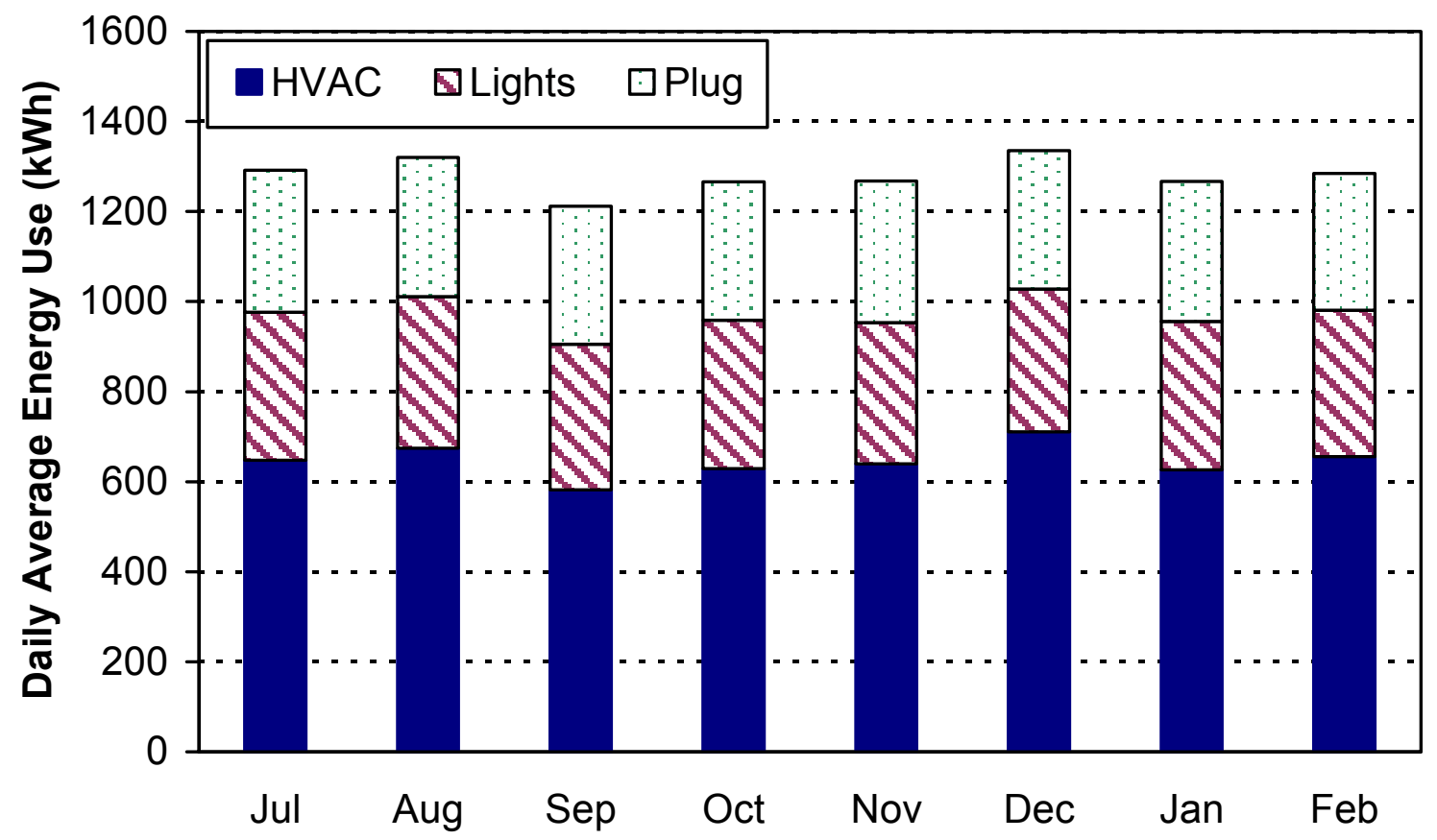

Figure 3. Daily average energy use for weekdays from July 2001 to February 2002 


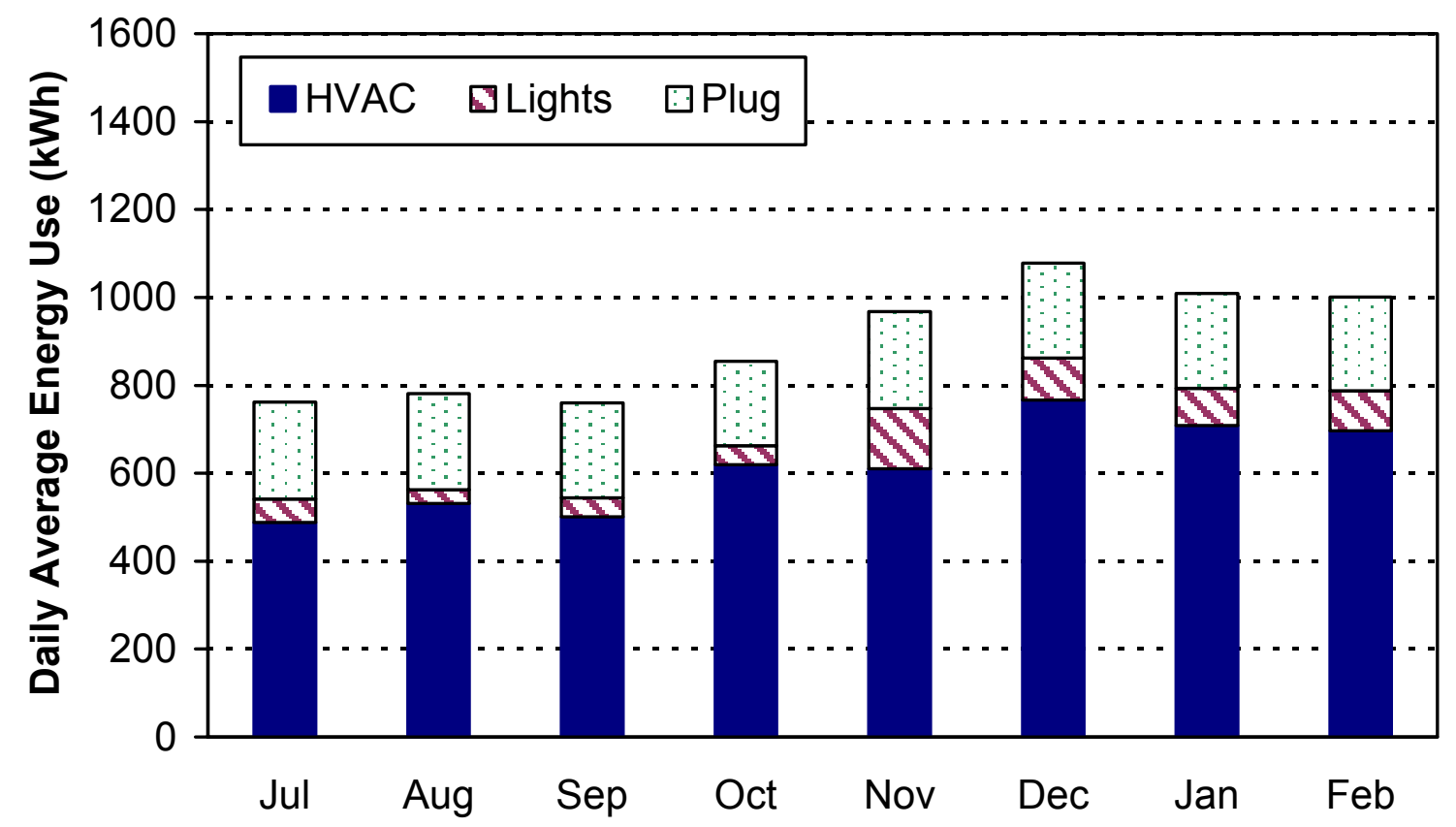

Figure 4. Daily average energy use for weekends/holidays from July 2001 to February 2002

Another way to examine energy use is to plot the average daily load profiles by month. This aggregates the monthly data into one graph and allows a view of the daily and seasonal variations. Daily load profiles were created based on the PowerLogic ${ }^{\circledR}$ data for weekdays and for weekends/holidays for July 2001 to February 2002. The weekday profiles for July, October, and January are shown in Figures 5 to 8. The load profiles are similar, which is expected for an office building with a regular schedule. The total building profile in Figure 5 shows some seasonal effects. The main reason for the differences is shown in Figure 6, which reveals the higher nighttime HVAC loads in the winter and the higher afternoon cooling loads in the summer. The peak use in July occurs between 2:00 p.m. and 3:00 p.m. (cooling load) and between 7:00 p.m. and 8:00 a.m. in January when the building lights come on in the morning while the heating load is still high. There are minor monthly variations in the lighting energy (Figure 7). The lights came on one hour later in January because of a change in the janitors' schedule. They turned on all the lights and left them on while cleaning. This schedule change occurred at the end of October and follows from recommendation 7.5. The night lighting load is mainly the outside lights, which turn on later in July, producing the drop in the lighting energy for the evenings in July. The morning and afternoon peaks in the January lighting load profile are due to a load in the $1^{\text {st }}$ E Light Panel. The plug loads are consistent from month to month, and they are quite large at night. There is a dip in plug loads around midday. 


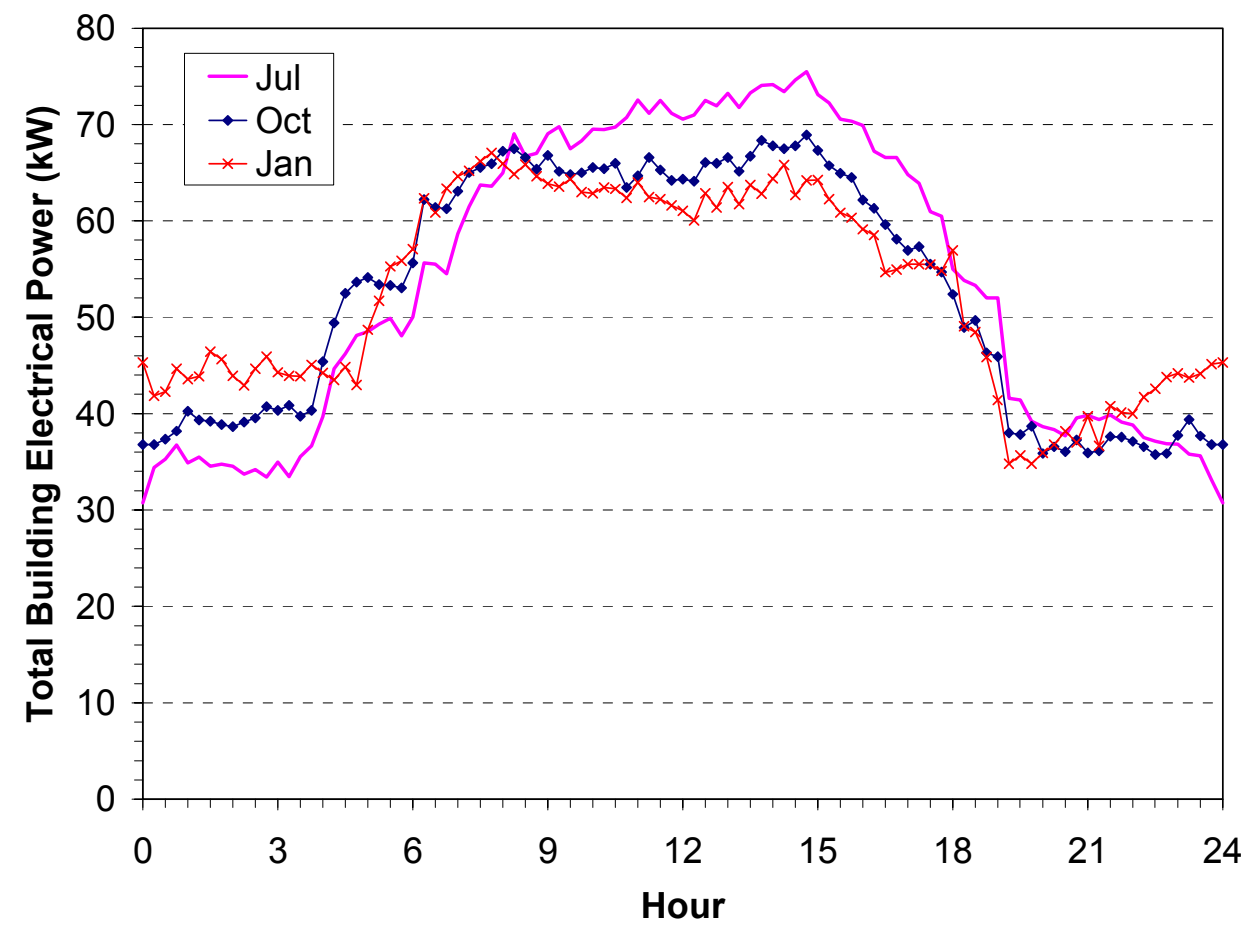

Figure 5. Daily total building load profile for weekdays

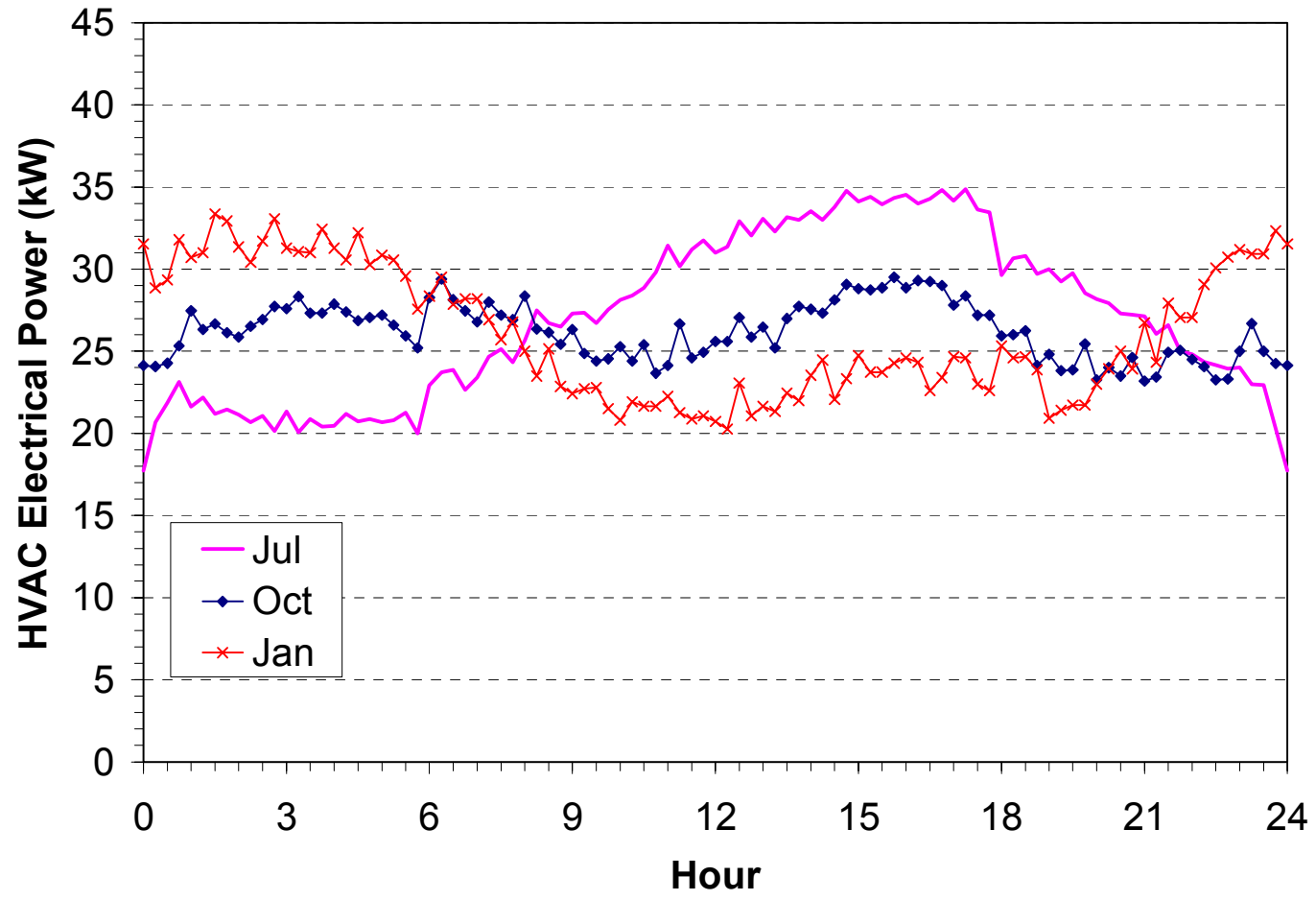

Figure 6. Daily HVAC load profile for weekdays 


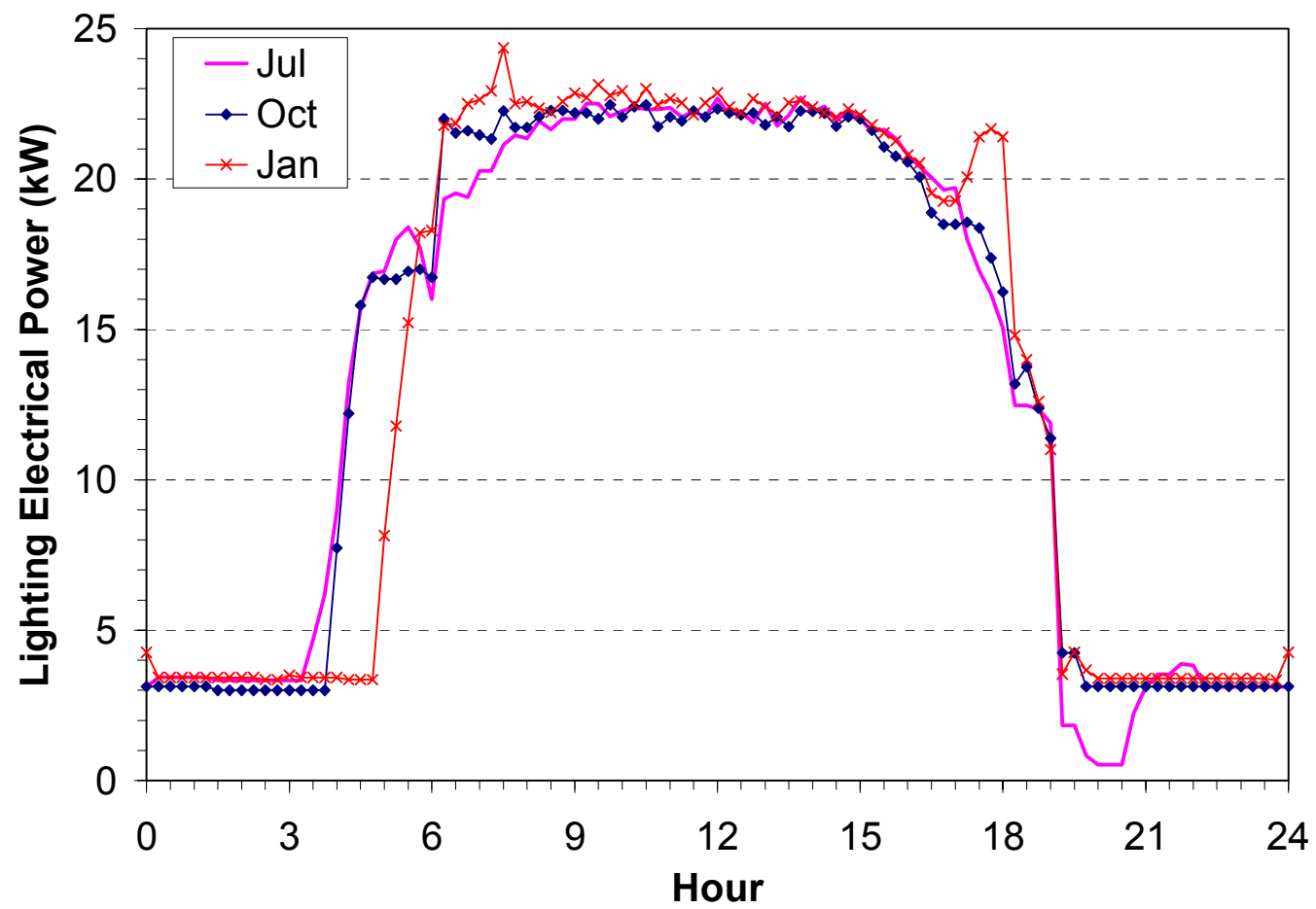

Figure 7. Daily lighting load profile for weekdays

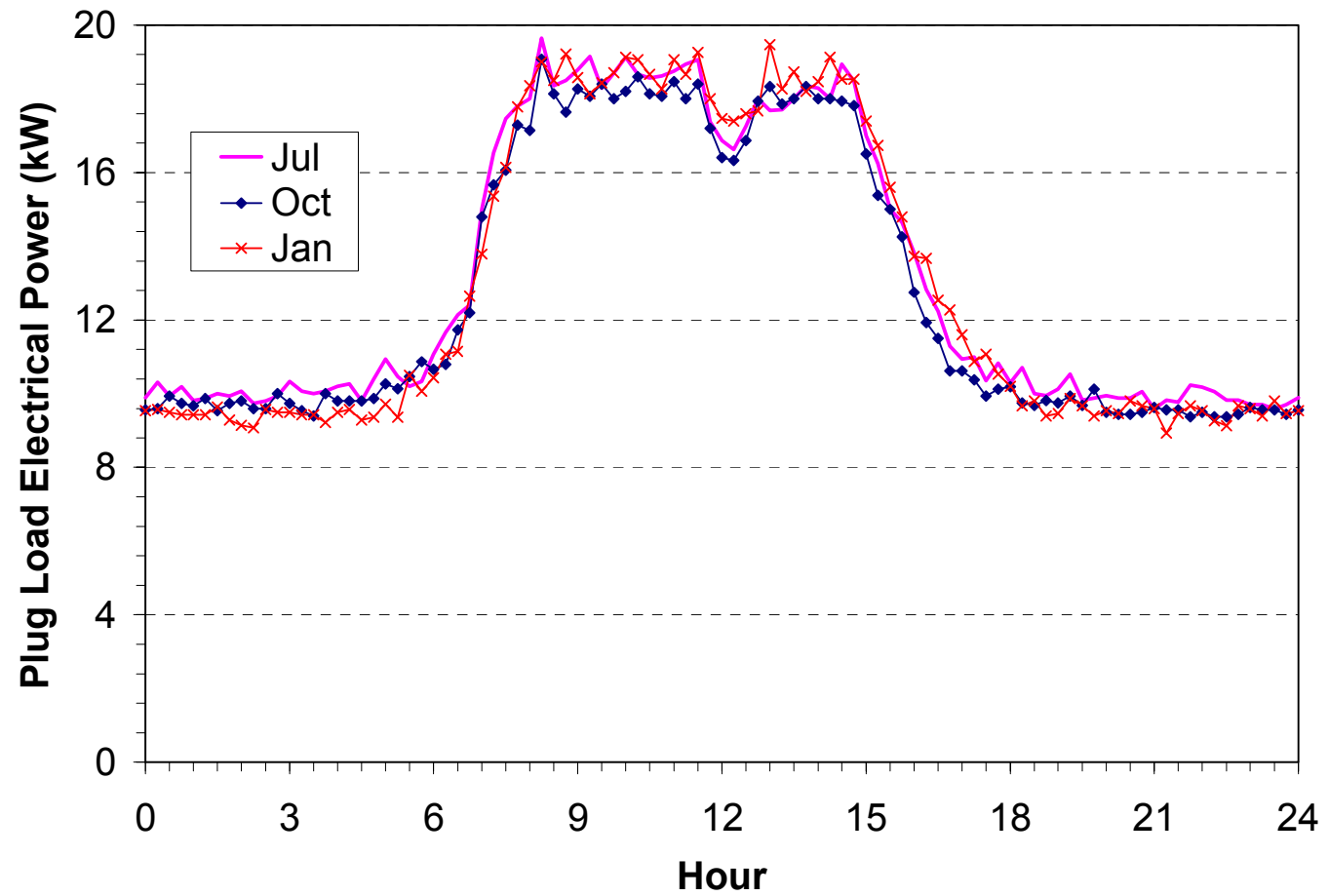

Figure 8. Daily plug load profile for weekdays 
As mentioned earlier, the HVAC systems are the largest loads. The two HVAC electrical panels include all heat pumps, circulating pumps, heat-recovery ventilators (HRVs), and the domestic hot water heater on the $1^{\text {st }}$ E Heat Panel. The 1-kW PV system feeds into the $1^{\text {st }}$ E Heat Panel and reduces its load slightly. The major heating panel loads and typical power consumptions measured by hand are listed in Table 2 .

Table 2. Loads on $1^{\text {st }} E$ and $1^{\text {st }} W$ Heat Panels

\begin{tabular}{|l|l|c|}
\hline \multicolumn{1}{|c|}{ Panel } & \multicolumn{1}{|c|}{ Load } & $\begin{array}{c}\text { Typical Value } \\
(\mathbf{k W})\end{array}$ \\
\hline \hline \multirow{5}{*}{$1^{\text {st }}$ E Heat } & Water heater & 3.9 \\
\cline { 2 - 3 } & Fans & 3.6 \\
\cline { 2 - 3 } & 10 circ pumps (total) & 1.9 \\
\cline { 2 - 3 } & HRV & 4.5 \\
\cline { 2 - 3 } & HPs 11-15 & varies \\
\hline \hline \multirow{3}{*}{$1^{\text {st }}$ W Heat } & Fans & 5.0 \\
\cline { 2 - 3 } & 11 circ pumps (total) & 2.16 \\
\cline { 2 - 3 } & HRV & 8.5 \\
\cline { 2 - 3 } & HPs 1-6 & varies \\
\hline
\end{tabular}

The fans and circulation pumps run continuously because the simple thermostats controlling the heat pumps were not programmed to allow them to cycle on demand. The east HRV runs from 7:00 a.m. to 6:00 p.m. Monday through Friday. Its internal calendar was slow by one day, so it used Sunday's schedule for Monday and Friday's schedule for Saturday. The NREL researchers corrected the calendar in the controller on July 14, 2001. The controller on the west HRV was not set up to turn the HRV off, so it runs 24 hours a day, 7 days a week. The heat pump compressors and heaters cycle as required and produce highly variable loads. Heat pumps 5 and 6 have duct heaters, which are not connected, and the remaining nine heat pumps have integral electrical resistance heaters, which are connected.

The next largest loads are the lighting panels. Most loads on the EMR (emergency) panel are the egress lights, which are on during the day. The first floor has fewer normally occupied areas, which is evident in the light loads (Table 1). The total lighting load in the building is difficult to estimate because the task lighting is included in the plug loads. Prior to the end of October 2001, the office lights were typically turned on at 4:00 a.m. and turned off at 7:00 p.m. After October 2001, the office lights are typically turned on at 5:00 a.m. The nighttime lighting load (mainly outside lights) is approximately $3 \mathrm{~kW}$.

The plug loads in the building consist mainly of computers, monitors, printers, task lights, and other office equipment. The total load varies between $10 \mathrm{~kW}$ at night and on weekends to approximately $18 \mathrm{~kW}$ during the occupied hours. NREL researchers conducted an informal survey of the plug loads in the office areas after business hours on the evening of Friday, July 13, 2001. Results are shown in Table 3. Some docking stations had no laptop computer attached; therefore, the actual number of laptop computers used in the building is higher than the total shown. 
Table 3. Numbers of Office Area Plug Loads on the Evening of 7/13/2001

\begin{tabular}{|l|c|c|c|c|}
\hline \multicolumn{1}{|c|}{ Load } & $\mathbf{1}^{\text {st }}$ Floor & $\mathbf{2}^{\text {nd }}$ Floor & Total & $\begin{array}{c}\text { On or } \\
\text { Standby }\end{array}$ \\
\hline \hline $\begin{array}{l}\text { Desktop } \\
\text { computers }\end{array}$ & 13 & 72 & 85 & 54 \\
\hline Laptop computers & 5 & 6 & 11 & 0 \\
\hline Monitors & 17 & 82 & 99 & 90 \\
\hline Printers/scanners & 10 & 64 & 74 & 74 \\
\hline Copiers & 1 & 3 & 4 & 3 \\
\hline Fax machines & 1 & 1 & 2 & 2 \\
\hline Plotters and misc. & 0 & 4 & 4 & 1 \\
\hline Refrigerators & & 4 & 4 & 4 \\
\hline
\end{tabular}

The numbers and types of equipment left on or in standby were also noted during the survey. Most desktop computers were left on. Their exact power draw is not known, but most desktop computers draw $40-80 \mathrm{~W}$ in normal operation. Most operating systems have a power management feature that will put the computer in standby after a certain period; however, these features are usually not set up and reduce the power consumption by only a few watts when they are in operation. Many CRT monitors in standby mode use 3-10 W; however, older monitors do not have a standby mode and may use around $40 \mathrm{~W}$ when turned on with a blank screen.

\section{Photovoltaic System Performance}

The performance of the main PV system is monitored by a utility-type meter that is read monthly for billing purposes. Prior to July 2002, there was no detailed monitoring of the two PV systems. The average daily purchased energy as billed from the utility company and the average daily energy from the main PV system are shown in Figure 9 for June 2001 to January 2002. The height of the columns is the total energy use of the building minus the energy production from the small PV system. The percent of the total building load met by the PV system is also included as a line graph. The systems were not continuously monitored, so determining the PV system performance is difficult. The peak output of the two PV systems is approximately $16 \mathrm{~kW}$, and the building energy use is always above $20 \mathrm{~kW}$ (usually well above $30 \mathrm{~kW}$ ); therefore, the PV systems never "sell" energy back to the utility. 


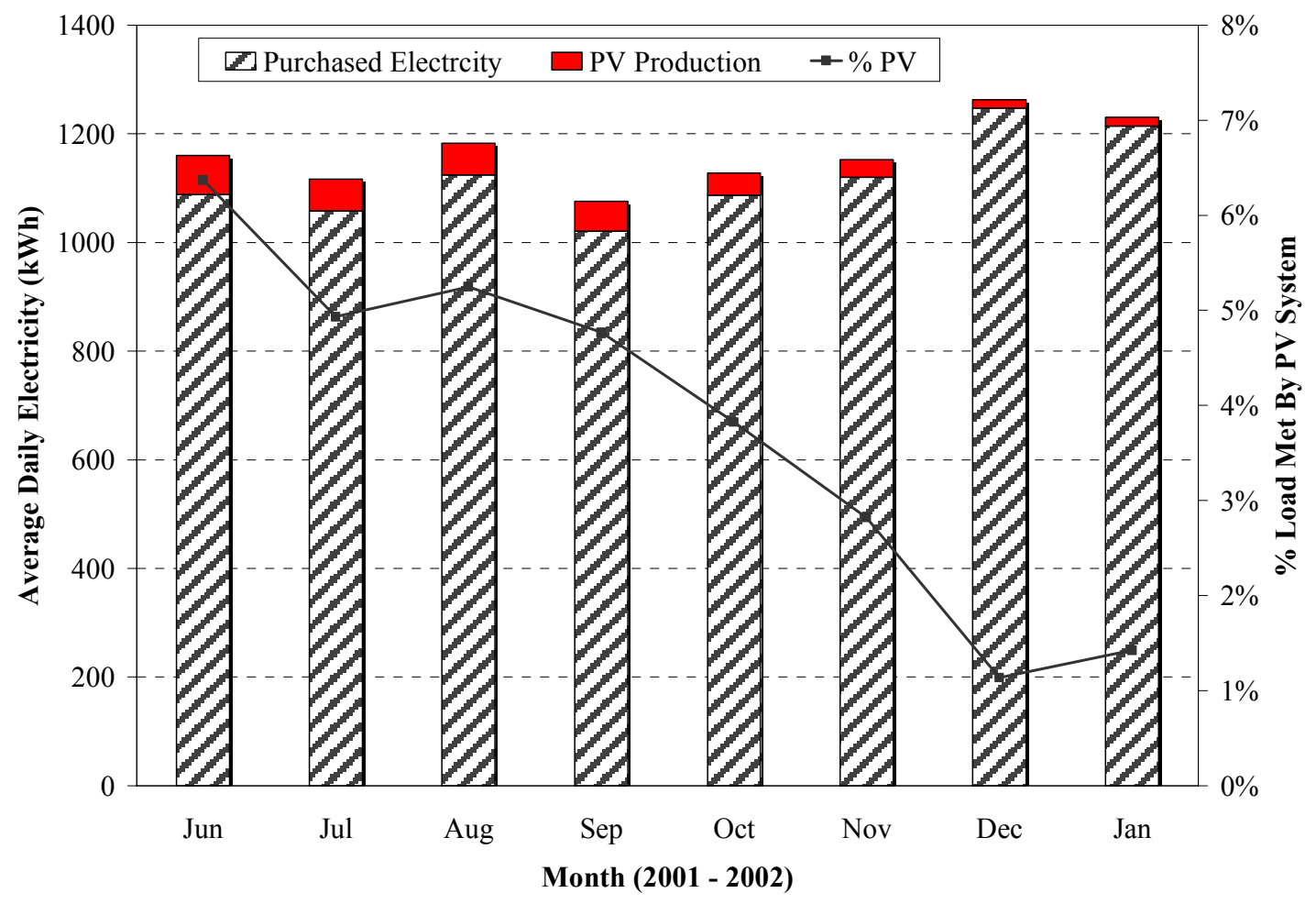

Figure 9. Average daily purchased energy and PV system performance

The performance of the main PV system was monitored Saturday and Sunday, July 14 and 15. The weather conditions on Saturday were mostly clear with some large cumulus clouds. Sunday was clear in the morning and partly cloudy by midday. On Saturday, the system was monitored with handheld measurements and with the inverter's internal data logger. Over the monitoring period of approximately one hour at midday, the inverter experienced four high $\mathrm{AC}$ voltage faults. The system shuts down and goes through a six-minute test and warm-up period after each fault. The faults seemed to occur when changing sky conditions caused the system output to increase rapidly toward the maximum inverter output of $15 \mathrm{~kW}$. Unfortunately, difficulties with the internal data logger prevented data from being collected during these faults. On Sunday, a portable power meter was attached to the system from approximately 9:00 a.m. to 4:30 p.m. The data, in 15-second increments, are plotted in Figure 10. Interpreting the sky conditions of a clear morning and intermittent clouds by midday is easy. Under these conditions, the system produced $75 \mathrm{kWh}$ of electricity. 


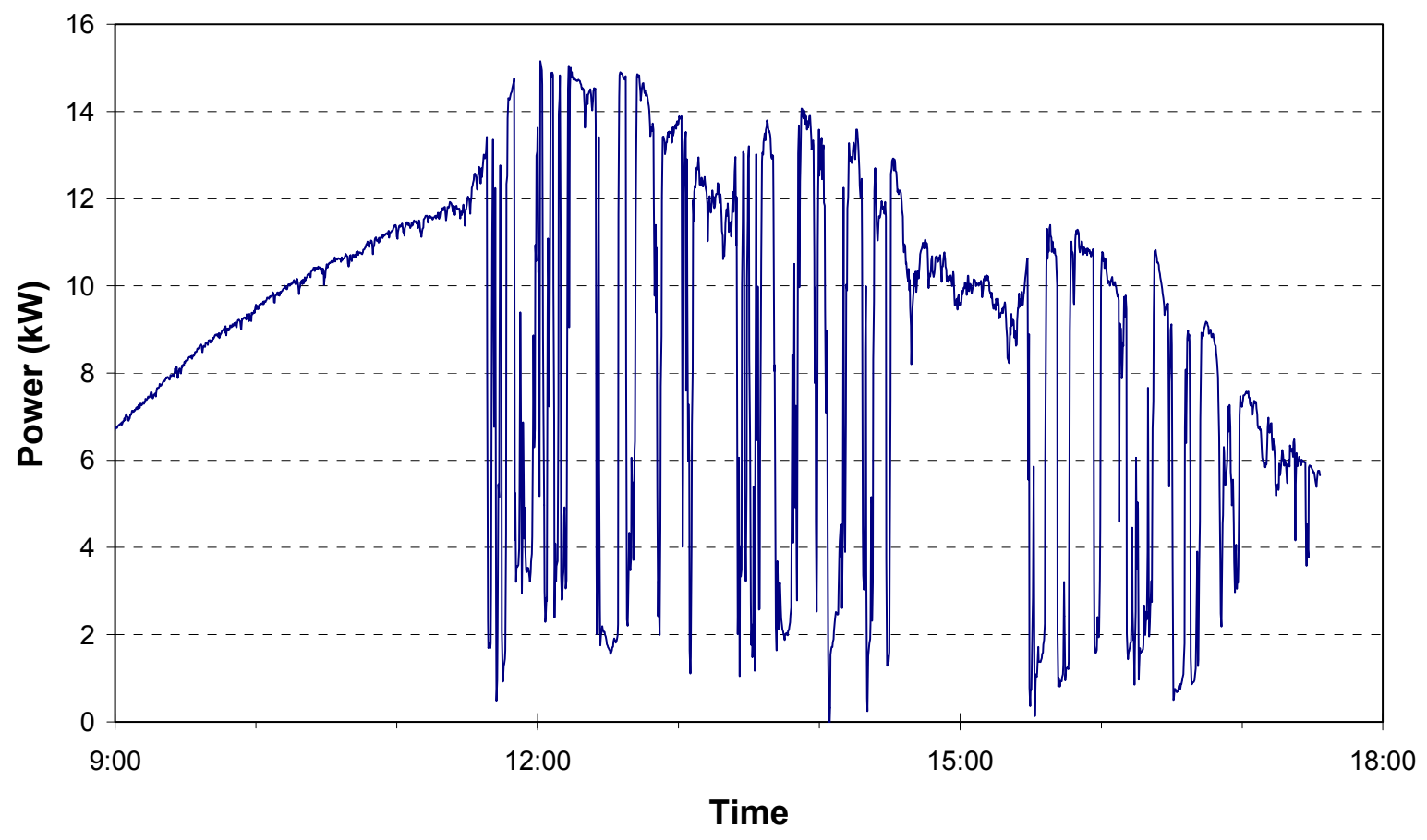

Figure 10. PV system performance on Sunday, July 15, 2001 with Eastern Daylight Saving Time

\section{Lighting Measurements}

The outdoor and indoor illuminances were monitored continuously from Friday to Monday, July 13-16, 2001. The outdoor illuminance is shown in Figure 11 in the units of foot-candles (fc) and lux. The first three days were mostly sunny with occasional cumulus clouds, and the final day was cloudy in the morning with some clearing by the afternoon. The indoor light levels were measured in rows of three cubicles along a north-south cross section in the first and second floor west office areas. Two to three photometers were placed in each cubicle: one in front of the keyboard and the others on the working area of the desk (see Figure 12). Illuminance of the electric lights only was measured between 9:00 p.m. and 10:00 p.m. on Friday, July 13. The recommended minimum illuminance levels on a horizontal surface for general office work is $30 \mathrm{fc}$ (IESNA 2000). 


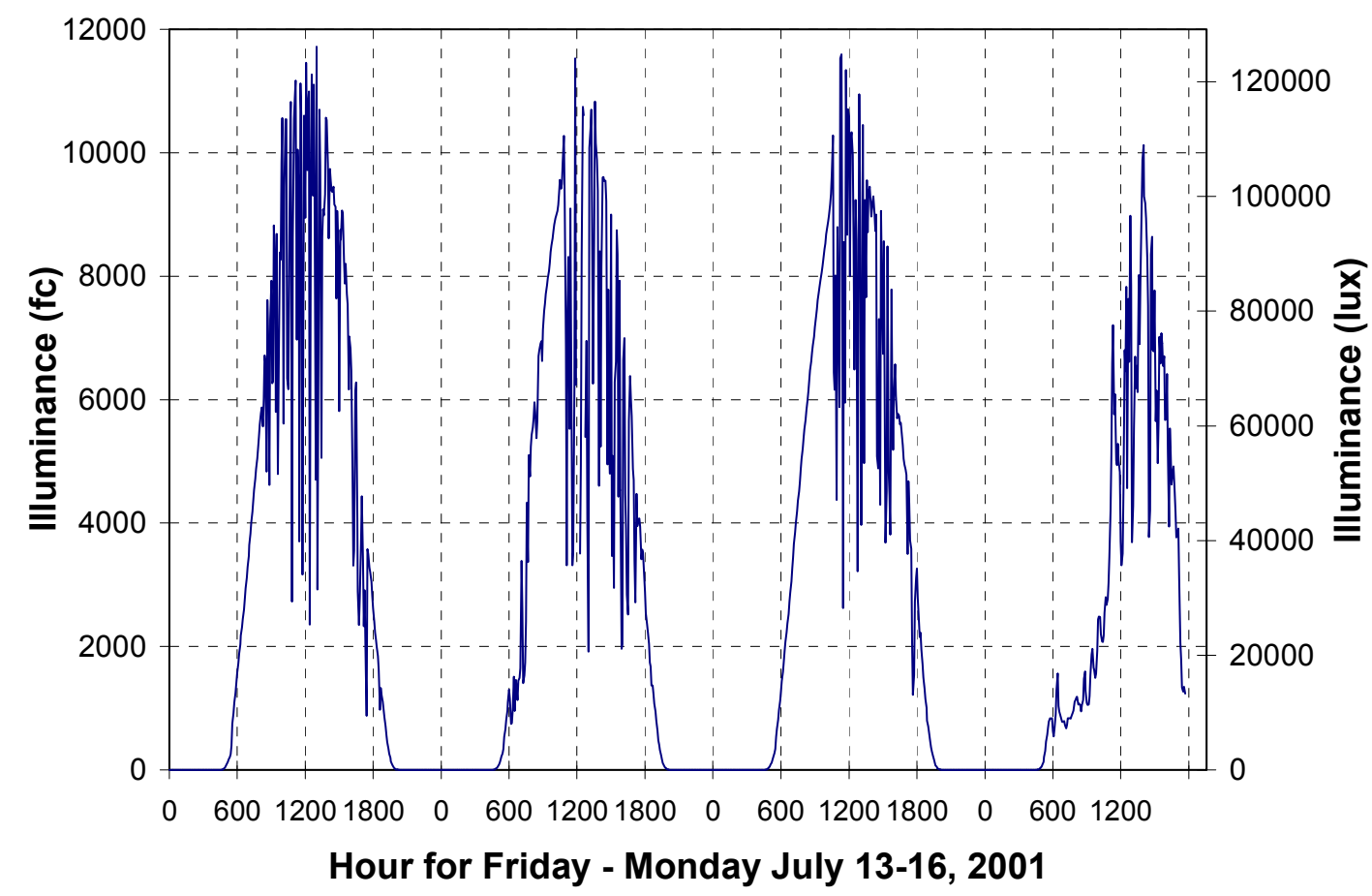

Figure 11. Outdoor illuminance for July 13-16, 2001

The first floor has a large open office area in the southwest quadrant and closed offices in the center. Natural lighting is provided in the open office area by eight windows with direct gain on the bottom section and light shelves on the top section, as seen in the external view in Figure 1. The ceiling has highly reflective tiles; the bottom $2.5 \mathrm{ft}$ of the walls are a light, natural wood color; the top portions of the walls are painted off-white; the floor has black carpet; the fabric of the cubicle dividers is off-white; and the desks are black. A typical cubicle is shown in Figure 12. Area electric lights are indirect with an installed capacity of approximately $0.75 \mathrm{~W} / \mathrm{ft}^{2}$. The cubicles also have task lights under the bookshelves, which are controlled by the occupants and by occupancy sensors.

The light levels in the first floor office area are shown in Figure 13. The overhead electric lights were on Friday and Monday during working hours and Friday evening for testing, and they were off Saturday and Sunday. The task lights were off in the cubicles 18 and $26 \mathrm{ft}$ from the south wall, and they were on in the morning and afternoon in the cubicle $10 \mathrm{ft}$ from the south wall. The overhead electric lights produced 25$35 \mathrm{fc}$ on the working planes, and the combination of electric lights and natural light produced 30-40 fc. This is adequate light for working at a computer terminal and performing easy reading tasks; however, some individuals prefer more light for working. The task lights raise the light levels on the working surface to 60-100 fc. Over the weekend, the electric lights were off, and the natural light levels never exceeded $10 \mathrm{fc}$. The light shelves do not appear to be effective in this application. The reasons for their poor performance include the high angle of the sun in the summer, the small amount of glass area (the wide window frames block much of the light), and poor light reflection caused by the diffuse reflecting surface on the light shelves. The cubicle walls also block light sources that are not directly overhead. There is no effective daylighting in the first floor office area. 


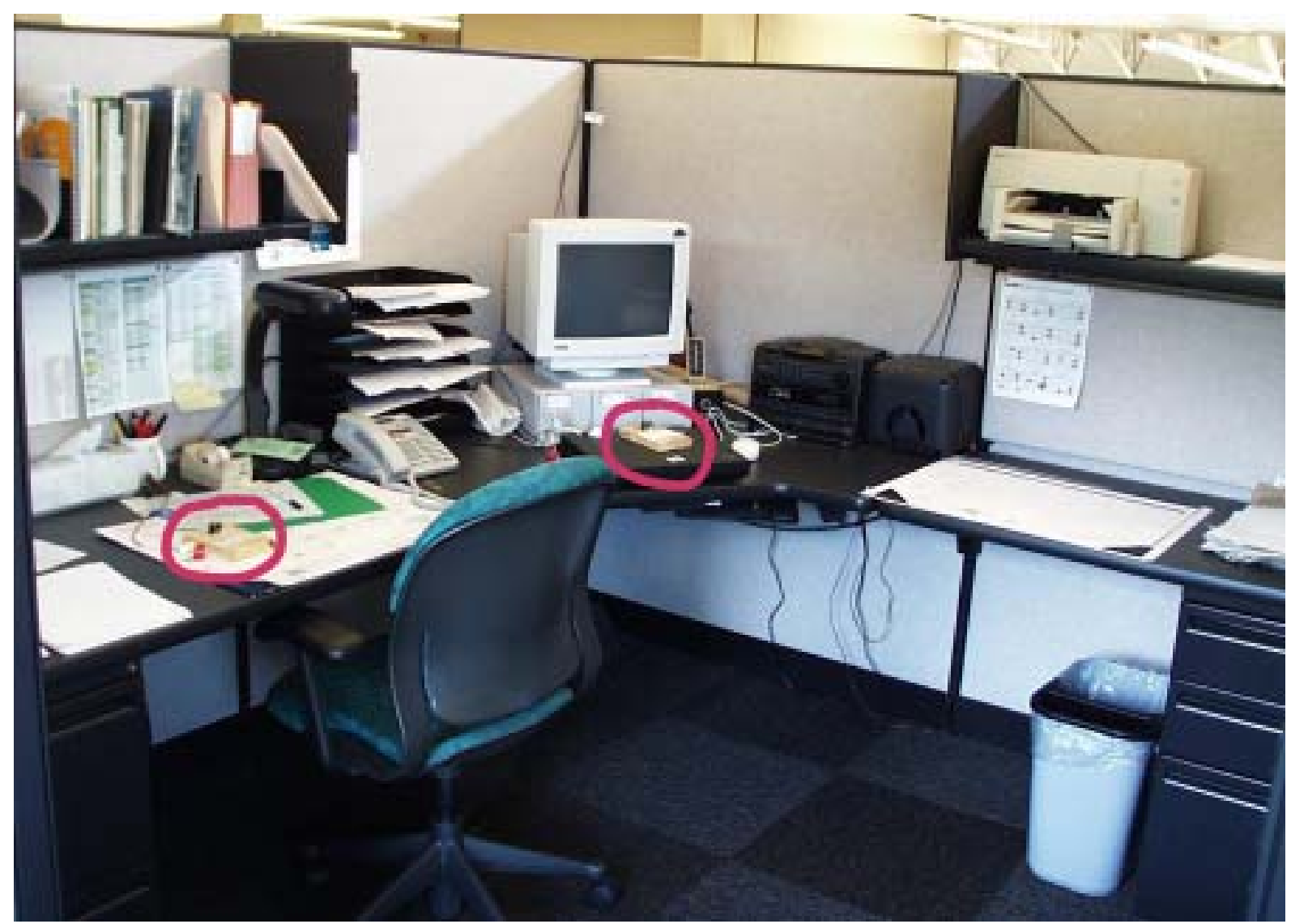

Figure 12. Placement of photometers (shown circled) on the working plane in a typical cubicle

The second floor has high vaulted white ceilings with an open truss construction. The roof is divided in two along the east-west axis to provide clerestory windows for the north and south office areas. Windows on the north and south walls also provide light. The walls, floors, and furnishings have similar colors as the first floor. Figures 14 and 15 show the measured illuminances for the second floor southwest and northwest office areas from Friday to Monday, July 13-16, 2001. The task lights were off except in the cubicle that is 18 feet from the north wall in the northwest office area. The electric lights were off over the weekend, except for the period between 5:30 a.m. and 9:00 a.m. on Saturday in the northwest office area. The natural light levels on the north side were slightly reduced by the east half of the clerestory sun blinds, which were in the down position for maintenance.

Illuminance from the electric lights was measured Friday evening between 9:00 p.m. and 10:00 p.m. The light levels at the workstations for both office areas were approximately $15 \mathrm{fc}$. This is lower than the first floor because the indirect luminaries do not reflect well off the high ceilings with trusses. The combination of electric lights and daylighting produced illuminances of 20-35 fc at midday. The natural light levels over the weekend were 10-25 fc on the working surfaces and 20-30 fc in the open circulation areas. The daylighting on the second floor is reduced because of the poor reflection off the high ceiling and the trusses, the dark floor, and the small amount of light from the windows on the outside walls is blocked by the cubicle dividers. The lighting on the second floor could also be improved with direct lighting luminaires. 


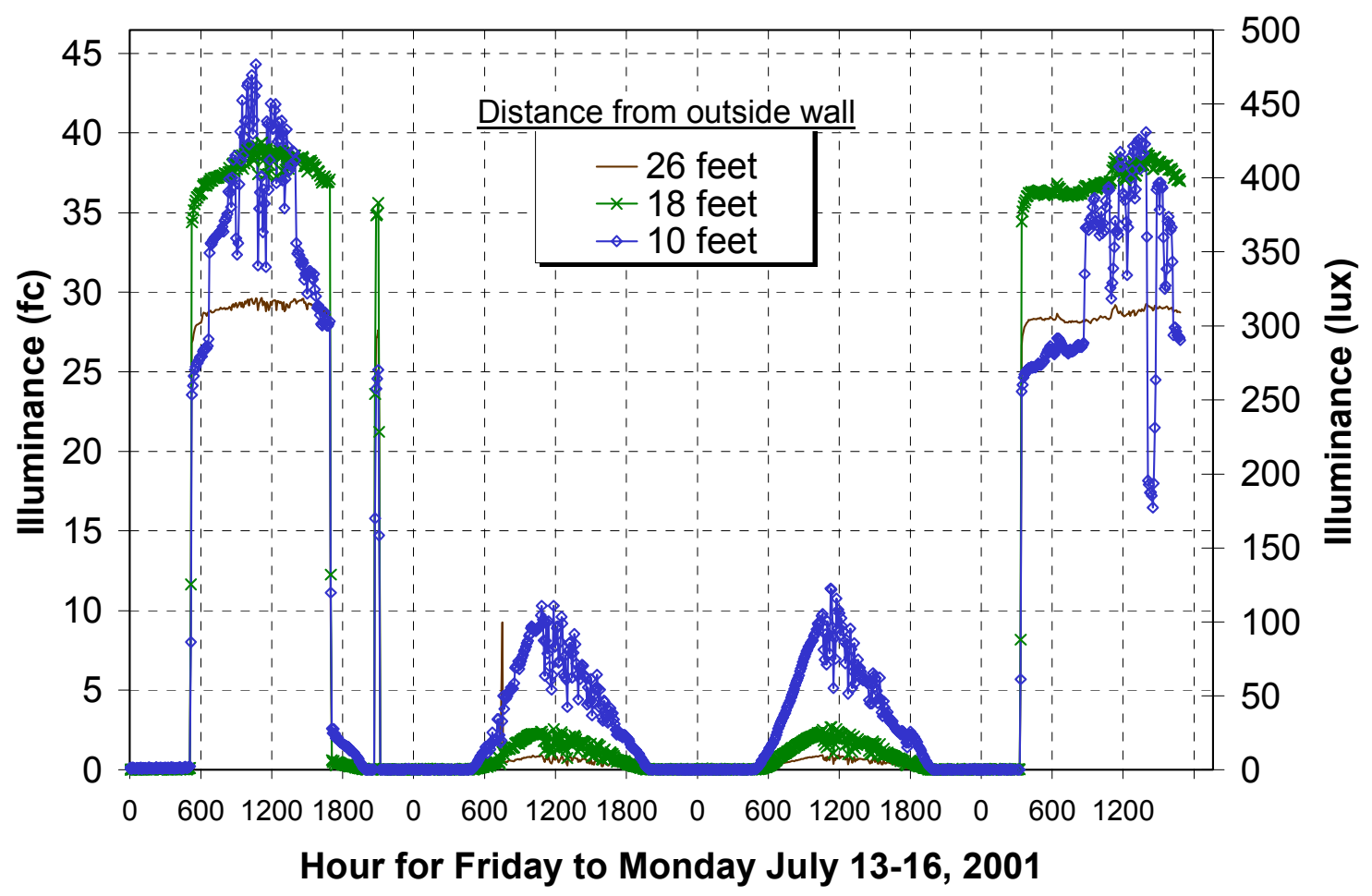

Figure 13. Daylighting measurements at workstations for the first floor office area on July 13-16, 2001

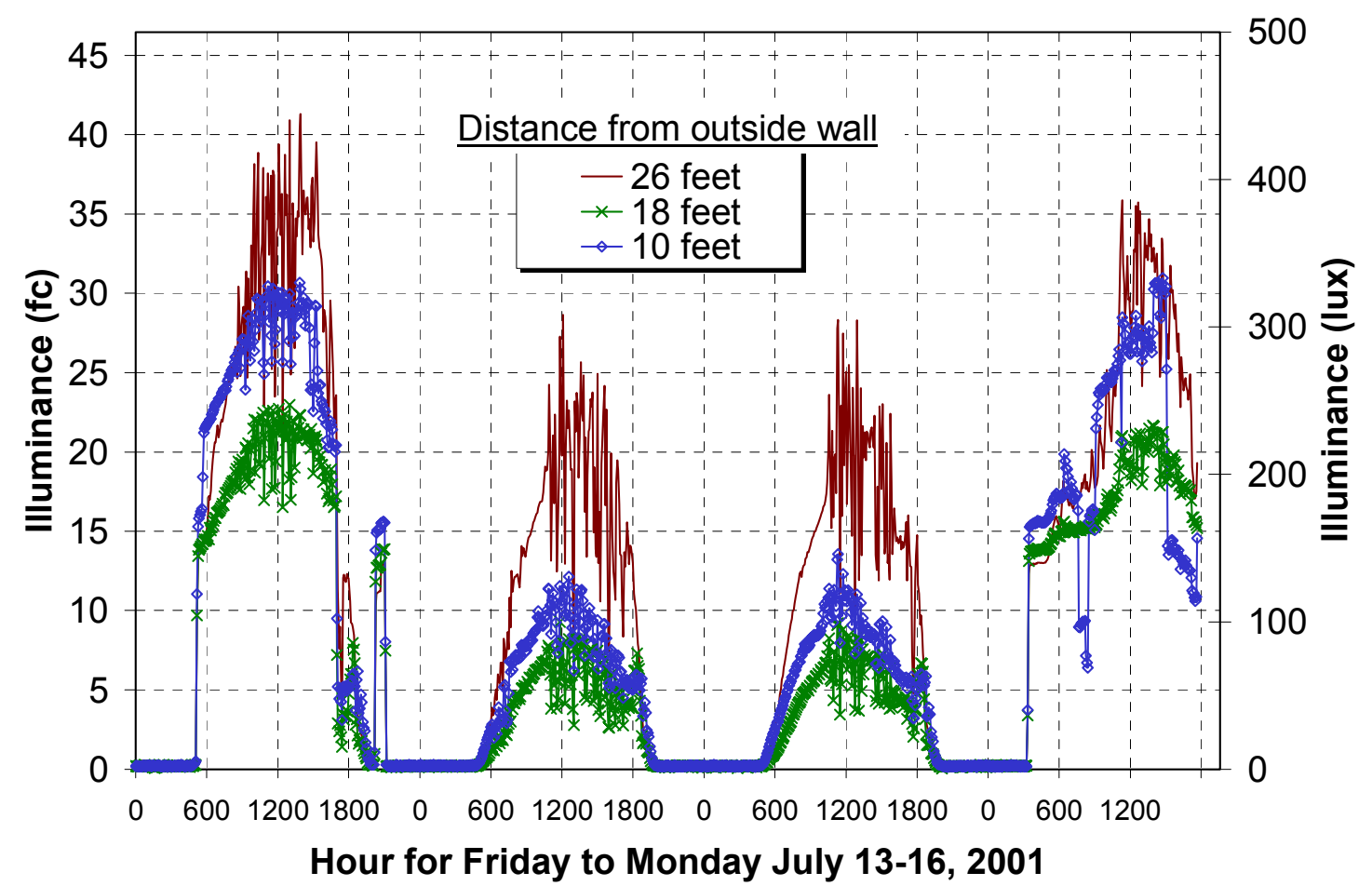

Figure 14. Daylighting measurements at workstations for the second floor southwest office area on July 13-16, 2001 


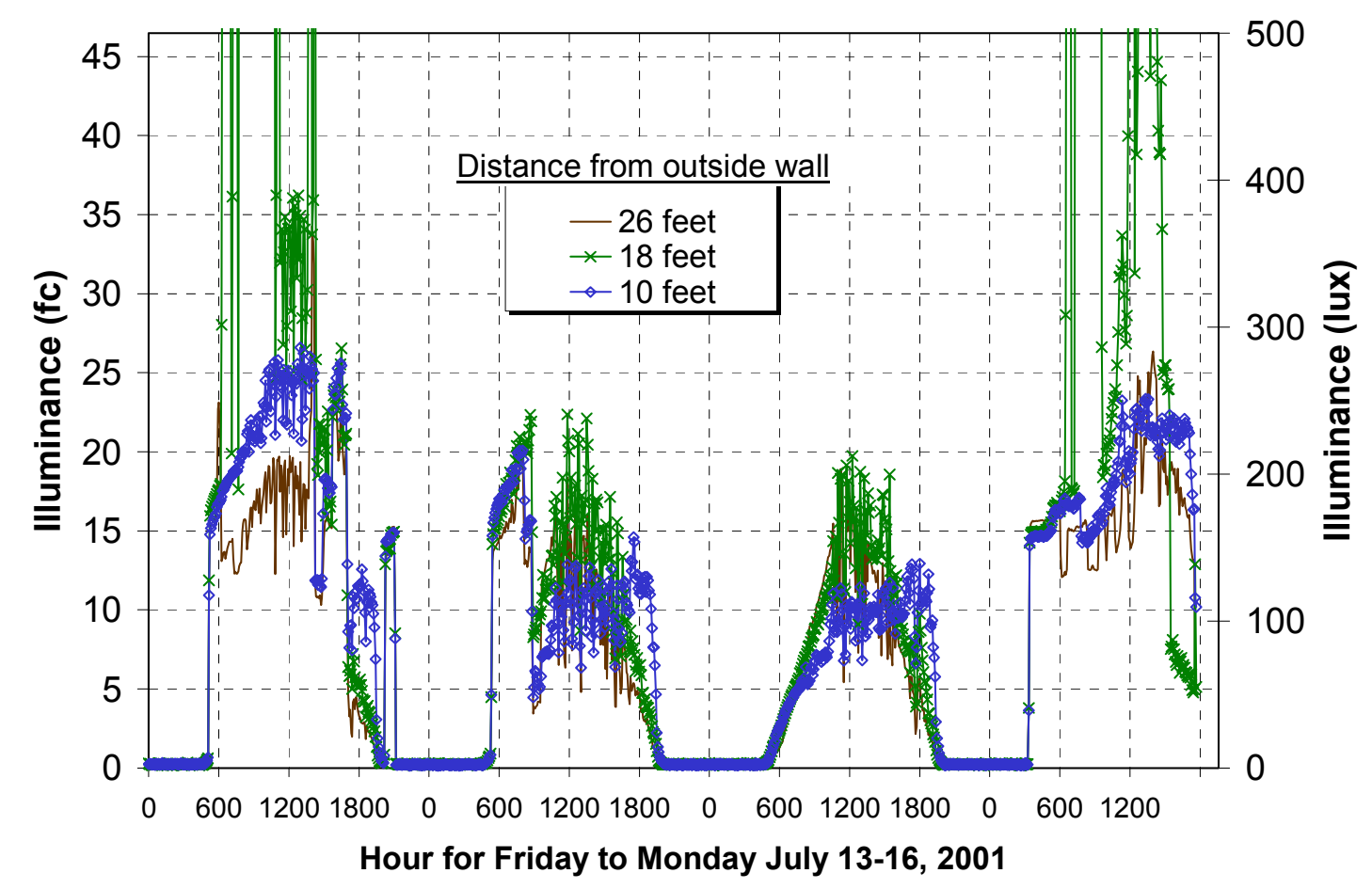

Figure 15. Daylighting measurements at workstations for the second floor northwest office area on July 13-16, 2001

Daylighting savings are defined as the fraction of the lighting electricity displaced by natural light contributions while maintaining the minimum illuminance levels (Atif et al. 1997). The illuminance measurements have shown that the light levels with the natural light and the electric lights are at or below the minimum illuminance level of $30 \mathrm{fc}$ for a horizontal working surface in an office (IESNA 2000). On the first floor, the natural light levels are extremely low and contribute little to the overall levels. The illuminance levels on the second floor with only the electric lights are below the minimum levels, and the combination of daylighting and electric lights on a sunny day is close to the minimum levels. According to this definition and these measurements, there are no daylighting savings. If the lights on the second floor are dimmed because of daylighting, a dip in the power consumption during the daylight hours would show up in the lighting power measurements for the second floor. This is not evident in any measurements.

However, the lighting design in this building uses less energy than a typical office building. The lower installed lighting power density relies on task lighting for demanding visual tasks. Some task lights are off at times because some occupants do not use them, some of the cubicles are vacant, and some occupants work in the field much of the time. Therefore, savings are associated with not having to constantly light the whole office to the higher levels. Estimating these savings is difficult because the task lights are included with the plug loads and their exact energy use is not known. The installed lighting power density in the office areas is about $0.75 \mathrm{~W} / \mathrm{ft}^{2}$ for the overhead lights and $0.5 \mathrm{~W} / \mathrm{ft}^{2}$ for task lights. Only about half the task lights are apparently in use. This means that the used lighting power density is approximately 1.0 $\mathrm{W} / \mathrm{ft}^{2}$, compared to a typical office building at $1.5 \mathrm{~W} / \mathrm{ft}^{2}$, which is a reduction of $33 \%$. Additional savings are achieved with compact fluorescent lamps and occupancy sensors in other areas. 


\section{Energy Conservation Measures}

NREL researchers analyzed data and performed visual inspections to identify several potential areas of energy conservation improvement. Each measure includes a background description and an estimate of its impact. The actual savings may be different depending on the effectiveness of the implementation, the interaction of all the building loads, occupant patterns, and weather conditions.

\subsection{Thermostat Control}

The building is always maintained between constant heating and cooling setpoints because the low flow of the under-floor distribution system with a massive floor is thought to be slow to respond to changes in the setpoint. The large thermal inertia of the building should not preclude a night setback in the heating season and a night setup in the cooling season; it only means that there is longer lag time to change the temperature. The importance of using a night setback in the winter is evident in the HVAC loads in October and January (Figure 6), which actually increase at night and on weekends. All the HVAC recommendations presented will be enhanced by using a night and weekend setback and night and weekend setup temperature setpoints. The energy savings associated with this can best be estimated by an hourly simulation of energy use. Tests of a night and weekend setback and a setup should be conducted to determine how the building will respond. These tests could be conducted on a weekend to see whether the HVAC system recovers the temperature before occupants arrive in the morning. As a first attempt, the temperature should be set back $10^{\circ} \mathrm{F}$ from 5:00 p.m. until 5:00 a.m., the power consumption monitored through the PowerLogic $₫$ system, and the temperature and $\mathrm{CO}_{2}$ monitored through the Campbell Scientific data logging system.

\subsection{Program Heat Recovery Ventilators}

During NREL's visit in July, the west HRV was observed to run 24 hours a day, 7 days a week and the east HRV from 7:00 a.m. to 7:00 p.m. 5 days a week. The units run at a constant speed and therefore draw approximately the same power whenever they are operating. Table 2 shows the measured power consumption is $8.5 \mathrm{~kW}$ and $4.5 \mathrm{~kW}$ for the west and east HRVs. Programming the units to run 10 hours per day (7:00 a.m.-5:00 p.m.) would reduce the weekday electrical energy use of the west unit by 119 $\mathrm{kWh} /$ day and of the east unit by $9 \mathrm{kWh} /$ day; the weekend energy use of the west unit would be reduced by $408 \mathrm{kWh} /$ day. This results in an annual saving of $\$ 3,814.72$, assuming $\$ 0.07 / \mathrm{kWh}$.

\begin{tabular}{|c|c|c|c|c|c|c|c|}
\hline Load & Qty & $\begin{array}{c}\text { Power } \\
\text { (W) }\end{array}$ & $\begin{array}{l}\text { Total } \\
\text { Power } \\
(\mathbf{k W})\end{array}$ & Action & \begin{tabular}{|c|} 
Power \\
Decrease \\
$(\mathbf{k W})$
\end{tabular} & \begin{tabular}{|c|} 
Energy \\
Savings \\
(kWh/yr)
\end{tabular} & $\begin{array}{c}\text { Annual } \\
\text { Savings } \\
\text { (\$.07/kWh) }\end{array}$ \\
\hline East HRV & 1 & 4500 & 4.5 & \multirow{3}{*}{$\begin{array}{l}\text { Program to run } \\
\text { 7:00 a.m. to 5:00 p.m. } \\
\end{array}$} & \begin{tabular}{|r|}
4.5 \\
\end{tabular} & 2340.0 & \begin{tabular}{|r|}
$\$ 163.80$ \\
\end{tabular} \\
\hline West HRV & 1 & 8500 & 8.5 & & 8.5 & 52156.0 & $\$ 3,650.92$ \\
\hline Total & & & 13 & & 13 & 54496.0 & $\$ 3,814.72$ \\
\hline
\end{tabular}

The building contractor reportedly reprogrammed both HRVs to run from 5:00 a.m. to 7:00 p.m. on December 11, 2001. The runtimes were extended to provide better flushing of the building. This change should show up in the energy measurements in the HVAC panels; however, there is no indication of a change in the operation of the west HRV. There is a drop in the energy consumption for 15 minutes on the afternoon of December 11, indicating that the west HRV was turned off briefly, but the remaining 
energy data indicate that it ran continuously. Running the HRV at night also contributes to the heating load because the heat pumps have to heat the large amount of outside air brought into the building.

The cost-effectiveness of running the HRVs was not estimated; however, this should be considered. Operating the units when the temperature difference between the exhaust air and the outside air is small would not be cost-effective because less energy would be recovered from the exhaust air than would be used to run the fans. The only difficulty is getting enough outside air into the building to maintain acceptable $\mathrm{CO}_{2}$ levels when the HRVs are not in operation. The effectiveness of any operational changes would have to be tested while monitoring the $\mathrm{CO}_{2}$ levels.

\subsection{Heat Pump Control}

When the building was commissioned, the heat pumps operated in an occupied mode all the time, so the fans were always on. There is no need to run the fans continuously when the building is unoccupied; they should cycle as needed to maintain zone temperatures. Assuming that the duty cycle on the heat pumps is $25 \%$ during unoccupied times and the building is occupied from 7:00 a.m. to 5:00 p.m. on weekdays, this will save $\$ 2,657$. The building contractor reportedly corrected this problem and reprogrammed the thermostats on December 11,2001; however, very little will be saved until the heating and cooling setpoints are relaxed during unoccupied times.

Table 5. Heat Pump Fan Cycle-on-Demand Savings

\begin{tabular}{c|c|c|c|c|r|r|r} 
Load & Qty & $\begin{array}{c}\text { Avg } \\
\text { Power } \\
\mathbf{( W )}\end{array}$ & $\begin{array}{c}\text { Total } \\
\text { Power } \\
\mathbf{( k W )}\end{array}$ & Action & $\begin{array}{c}\text { Power } \\
\text { Decrease } \\
\mathbf{( k W )}\end{array}$ & $\begin{array}{c}\text { Energy } \\
\text { Savings } \\
\mathbf{( k W h / y r )}\end{array}$ & $\begin{array}{c}\text { Annual } \\
\text { Savings } \\
\mathbf{( \$ . 0 7 / k W h )}\end{array}$ \\
\hline \hline Total fans & 11 & 750 & 8.25 & night cycle-on-demand & 8.25 & 37966.5 & $\$ 2,657.66$ \\
\hline Total & & & 8.25 & & 8.25 & 37966.5 & $\$ 2,657.66$
\end{tabular}

\subsection{Groundwater Circulation Pump Control}

Each heat pump has its own bank of groundwater circulation pumps that are mounted in series of one, two, or three pumps. The pumps are mounted in series to match the flow and head requirements of each heat pump. This configuration is not the most efficient but is often used because pump sizes may have limited availability and many contractors want to use only one type of pump. The pumps are rated at 230 $\mathrm{W}$ each but were measured to draw approximately $200 \mathrm{~W}$ each. The pumps are now run continuously; however, they need to be operated only when the compressor is running. There is concern that the capacitance effects of the ground might adversely affect the system when the pumps run in a cycling mode. According to Kavanaugh and Rafferty (1997), this is not a concern and the best method of operating the circulation pumps is to tie them to the compressor operation. A conservative estimate is that the compressors run an average of $25 \%$ of the time. The annual saving of linking the pumps with the compressors is then $\$ 1,932$. Again, this will depend on the temperature setpoints and will benefit from a night setback and night setup. 
Table 6. Groundwater Circulation Pump Savings

\begin{tabular}{r|r|r|r|r|r|r|r} 
Load & Qty & $\begin{array}{c}\text { Power } \\
\mathbf{( W )}\end{array}$ & $\begin{array}{c}\text { Total } \\
\text { Power } \\
\mathbf{( k W )}\end{array}$ & Action & $\begin{array}{c}\text { Power } \\
\text { Decrease } \\
\mathbf{( k W )}\end{array}$ & $\begin{array}{c}\text { Energy } \\
\text { Savings } \\
\mathbf{( k W h / y r )}\end{array}$ & $\begin{array}{c}\text { Annual } \\
\text { Savings } \\
\mathbf{( \$ . 0 7 / k W h )}\end{array}$ \\
\hline \hline Circ. pumps & 21 & 200 & 4.2 & cycle-on-demand & 4.2 & 27594 & $\$ 1,931.58$ \\
\hline Total & & & 4.2 & & 4.2 & 27594 & $\$ 1,931.58$
\end{tabular}

\subsection{Lighting Control}

There are two issues with the lights: (1) programming, and (2) the janitors' use of lights. All lights in the office and circulation areas are programmed to come on at 6:00 a.m. and go off at 7:00 p.m. A first observation of the occupancy patterns reveals that most people arrive around 7:00 a.m. and leave before 4:00 p.m. The lights should be reprogrammed to more closely reflect these patterns. The few people who arrive early or stay late can turn on the lights in their areas.

Until late October, all the office lights were turned on between 3:00 a.m. and 4:00 a.m. and left on until evening. The janitors changed their cleaning schedule to come in at 6:00 a.m. The lights now come on between 5:00 a.m. and 6:00 a.m., which saves about $\$ 595$ per year.

Table 7. Light Control Savings

\begin{tabular}{r|r|r|r|r|r|r|r} 
Load & Qty & $\begin{array}{c}\text { Power } \\
\mathbf{( W )}\end{array}$ & $\begin{array}{c}\text { Total } \\
\text { Power } \\
\mathbf{( k W )}\end{array}$ & Action & $\begin{array}{r}\text { Power } \\
\text { Decrease } \\
\mathbf{( k W )}\end{array}$ & $\begin{array}{r}\text { Energy } \\
\text { Savings } \\
\mathbf{( k W h / y r )}\end{array}$ & $\begin{array}{c}\text { Annual } \\
\text { Savings } \\
\mathbf{( \$ . 0 7 / k W h )}\end{array}$ \\
\hline \hline Interior lights & 1 & 17000 & 17 & Operate 7:00 a.m. - 5:30 p.m. & 17 & 6630 & $\$ 464.10$ \\
Interior lights & 1 & 17000 & 17 & Begin cleaning at 6:00 a.m. & 17 & 8500 & $\$ 595.00$ \\
\hline Total & & & & & & 15130 & $\$ 1,059.10$
\end{tabular}

\subsection{Control of Plug (Receptacle) Loads}

The plug loads average around $19 \mathrm{~kW}$ during the day and $10 \mathrm{~kW}$ at night and on weekends. The daily power consumption is in line with an average office building for approximately 80 employees, assuming $200 \mathrm{~W}$ per person plus other miscellaneous loads. An energy-efficient office would use less energy.

The high levels of night and weekend energy use can be reduced with some simple changes.

Approximately one-third of this load can be eliminated by turning off the computers, monitors, and printers at night. Desktop computers left in standby mode reduce their power consumption very little. A common misconception is that turning off computers at night will cause problems with the hard drives or CPUs. Monitors and printers in standby mode use 5-15 W of power. This is small for a few machines, but significant for the entire office. An estimate of the savings from turning off the computers, monitors, and printers at night is shown in Table 8 . The numbers of machines were determined during the survey of the building loads on Friday evening, July 13 . Almost $\$ 1,000$ can be saved by simply turning off the computers at night and another $\$ 300$ by turning off the monitors at night. The printers must be unplugged or plugged into a power strip that is turned off to eliminate power draw. In addition, the two monitors for the two personal computers in the information systems room, which log data from the PowerLogic ${ }^{\circledR}$ system and the space temperature and $\mathrm{CO}_{2}$ monitors, should be turned off when they are not in use. 
Table 8. Night and Weekend Plug Load Energy Savings

\begin{tabular}{|c|c|c|c|c|c|c|c|}
\hline Load & Qty & $\begin{array}{c}\text { Power } \\
\text { (W) }\end{array}$ & $\begin{array}{c}\text { Total } \\
\text { Power } \\
\text { (kW) }\end{array}$ & Action & \begin{tabular}{|c} 
Power \\
Decrease \\
(kW)
\end{tabular} & $\begin{array}{c}\text { Energy } \\
\text { Savings } \\
\text { (kWh/yr) }\end{array}$ & $\begin{array}{c}\text { Annual } \\
\text { Savings } \\
\text { (\$.07/kWh) }\end{array}$ \\
\hline Computers & 54 & $\begin{array}{ll}40 \\
4\end{array}$ & 2.16 & Turn off at night & 2.16 & 13253.8 & $\$ \$ \$ 927.76$ \\
\hline Monitors & 99 & 7 & 0.69 & Turn off at night & 0.69 & 4252.2 & $\$ 297.66$ \\
\hline Printer/scanner & 68 & 10 & 0.68 & Turn off at night & 0.68 & 4172.5 & $\$ 292.07$ \\
\hline IS room monitors & 2 & 40 & 0.08 & Turn off when not in use & 0.08 & 700.8 & $\$ 49.06$ \\
\hline $\begin{array}{r}\text { Total } \\
\end{array}$ & & & 3.61 & & 3.61 & 22379.3 & $\$ 1,566.55$ \\
\hline
\end{tabular}

Suggestions for reducing daytime energy consumption are listed in Table 9. The first option is to install VendingMiser ${ }^{\mathrm{TM}}$ controllers on the two vending machines in the lunchroom. The VendingMiser ${ }^{\mathrm{TM}}$ reduces energy use by $30 \%-50 \%$ depending on the location of the vending machines and the occupancy patterns in this space. Their exact energy use was not measured, but an average use is $350 \mathrm{~W}$ per machine. The VendingMiser ${ }^{\mathrm{TM}}$ controllers turn off the machines after 15 minutes if no one is in the area and cycles the machines periodically to keep the drinks cold. The calculation in Table 9 assumes a $40 \%$ reduction in energy use and shows an annual saving of $\$ 170$ for the two machines, which would pay for the VendingMisers ${ }^{\mathrm{TM}}$ in less than two years.

A policy for buying office equipment should be implemented. All office equipment should meet or exceed Energy Star ${ }^{\circledR}$ requirements. Policies can also be put in place to encourage the use of laptop computers and flat screen monitors. The combination of these two features can save approximately $\$ 3200$ in annual energy costs and reduce the material used in making and shipping the equipment. This building has almost one printer for each occupant; using 10 networked printers could cut the energy use by $\$ 750$ per year. The flat screen monitors also have a longer life span than traditional monitors and take up less desk space.

A policy for operating office equipment should also be implemented. Computer monitors should be programmed to enter standby mode after 10 or 15 minutes of inactivity. Monitors without energy-saving features should be on remote motion-sensor plug strips. Screen savers should only be used for 10-15 minutes because they do not save energy. All office equipment should be turned off when employees leave for the day. Cubicle occupancy sensors should be oriented so that they are not activated by people walking by the cube. These suggestions do not cover all plug loads. A detailed survey of all the plug loads in the building could reveal other opportunities for savings.

In addition to the energy savings from the equipment, there are also energy savings from the reduced cooling loads. For each kilowatt-hour of saved energy in the office equipment and lights, there is an additional $0.2-0.3 \mathrm{kWh}$ saving from the reduced cooling load. This is an annual average number that takes into account the increased heating load in the cold months. 
Table 9. Daytime Plug Load Energy Savings

\begin{tabular}{|c|c|c|c|c|c|c|c|}
\hline Load & Qty & $\begin{array}{c}\text { Power } \\
\text { (W) }\end{array}$ & $\begin{array}{c}\text { Total } \\
\text { Power } \\
(\mathrm{kW})\end{array}$ & Action & $\begin{array}{c}\text { Power } \\
\text { Decrease } \\
\text { (kW) }\end{array}$ & \begin{tabular}{|c} 
Energy \\
Savings \\
(kWh/yr)
\end{tabular} & $\begin{array}{c}\text { Annual } \\
\text { Savings } \\
\text { (\$.07/kWh) }\end{array}$ \\
\hline Vending machines & 2 & 350 & 0.70 & VendingMisers & 0.28 & 2452.8 & $\$ \$ 171.70$ \\
\hline Computers & 85 & 40 & 3.40 & Use laptops & 2.55 & 22338.0 & $\$ 1,563.66$ \\
\hline Monitors & 99 & 80 & 7.92 & Use flat screens & 6.44 & 23423.4 & $\$ 1,639.64$ \\
\hline Printer/scanner & 68 & 30 & 2.04 & Use network printers & 1.74 & 10676.6 & $\$ 747.36$ \\
\hline $\begin{array}{ll}\text { Total } \\
\end{array}$ & & & 13.36 & & 10.73 & 56438.0 & $\$ 4,122.36$ \\
\hline
\end{tabular}

\subsection{Miscellaneous}

The background noise in the second floor office area is very low, which along with the open office design, allows sound to travel very well across the office. Most buildings have enough white noise from the HVAC system and the lights to cancel out some of these sound waves. Adding white noise generators can effectively dampen noises in open office buildings. One white noise generator placed in each quadrant of the second floor would eliminate much of the noise problem.

\section{Future Work}

NREL researchers will continue to monitor the building for at least one more year to evaluate operational changes. The performance will also be compared with a computer simulation of a baseline building that meets the ASHRAE/IESNA Standard 90.1-2001 for energy efficiency in commercial buildings (ASHRAE 2001). In addition, monitoring equipment has been added to the two PV systems to more accurately analyze their performance. A final technical report, which will include the work in this report and the analysis of the new data, will be completed by Fall 2003.

\section{Conclusions}

The energy use intensity for this building in 2001 was $43 \mathrm{kBtu} / \mathrm{ft}^{2} / \mathrm{yr}$, which is nearly half the energy use of a typical office building for this region. Because of the strong energy-efficient features in this building, its performance could be improved even more with minor adjustments. The energy-efficient features of the building include the well-insulated envelope, high-performance windows, ground source heat pumps, under-floor air distribution system, and parts of the lighting design. In addition, the PV systems supply some energy requirements.

Implementing the energy saving measures in Sections $7.1-7.6$ could reduce the EUI to $27 \mathrm{kBtu} / \mathrm{ft}^{2} / \mathrm{yr}$. The real energy savings will depend on how well the strategies are implemented and how they interact. One issue that may make implementing conservation measures difficult is that the owner of the building is not the occupant and does not pay the utility bills. The Pennsylvania DEP occupies the building, pays the utility bills, and therefore has incentive to improve the energy efficiency of the building; however, the DEP may have to receive permission from the owner to make changes to the building. In addition, one person working in the building needs to champion the energy conservation measures and monitor them to ensure their success.

There are some important lessons to be learned from the design, construction, and operation of this building. Some are common to other buildings and some are unique to this one. 
1. The whole-design approach worked to produce a good building; however, there are always areas that need improvement. An energy-efficient building requires a high level of monitoring and finetuning in the beginning; this high level decreases to a minimal level after a few years. The occupants also need to be educated about their energy use.

2. The mechanical engineer and the contractor apparently misunderstood the energy consultant's assumption in the HVAC design and operation. This resulted in energy-inefficient control strategies.

3. The daylighting design is not as effective as anticipated. The first floor would be improved by more glass area and lower cubicle dividers near the outside wall. The second floor would be improved by more clerestory glass area and some method of directing this light toward the ceiling, such as a louvered light shelf system.

4. The lighting system on the second floor could be improved with direct lighting fixtures.

5. The effects of occupant behavior on the light and plug loads are difficult to predict.

\section{References}

ASHRAE. (2001). ANSI/ASHRAE/IESNA Standard 90.1-2001, Energy Standard for Buildings Except Low-Rise Residential Buildings, American Society of Heating, Refrigerating, and Air-Conditioning Engineers, Atlanta, GA.

Atif, M. R.; Love, J. A.; Littlefair, P. (1997). Daylighting Monitoring Protocols and Procedures for Building, International Energy Agency Task 21, Annex 29, National Research Council Canada, NRCC 41369.

EIA. (2002). 1999 Commercial Buildings Energy Consumption Surveys, Energy Information Administration, U.S. Department of Energy, http://www.eia.doe.gov/.

IESNA. (2000). The IESNA Lighting Handbook, ninth edition, Illuminating Engineering Society of North America, New York.

Kavanaugh, S. P.; Rafferty, K. (1997). Ground Source Heat Pumps, American Society of Heating, Refrigerating, and Air Conditioning Engineers, Inc., Atlanta, GA. 


\section{REPORT DOCUMENTATION PAGE}

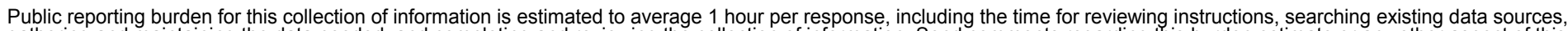

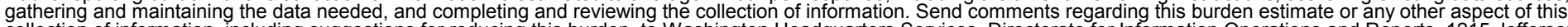
Washington Headquarters Services, Directorate for Davis Highway, Suite 1204, Arlington, VA 22202-4302, and to the Office of Management and Budget, Paperwork Reduction Project (0704-0188), Washington, DC 20503.
1. AGENCY USE ONLY (Leave blank)
2. REPORT DATE January 2003
3. REPORT TYPE AND DATES COVERED
Technical Report

4. TITLE AND SUBTITLE

Preliminary Energy Analysis of the Pennsylvania Department of Environmental

Protection's Cambria Office Building, Ebensburg, PA
5. FUNDING NUMBERS

BEC24002

6. $\operatorname{AUTHOR}(\mathrm{S})$

M. Deru and E. Hancock

7. PERFORMING ORGANIZATION NAME(S) AND ADDRESS(ES)

National Renewable Energy Laboratory

1617 Cole Blvd.

Golden, CO 80401-3393

9. SPONSORING/MONITORING AGENCY NAME(S) AND ADDRESS(ES)
8. PERFORMING ORGANIZATION REPORT NUMBER

NREL/TP-550-33106

10. SPONSORING/MONITORING AGENCY REPORT NUMBER

11. SUPPLEMENTARY NOTES

12a. DISTRIBUTION/AVAILABILITY STATEMENT

National Technical Information Service

U.S. Department of Commerce

5285 Port Royal Road

Springfield, VA 22161

13. ABSTRACT (Maximum 200 words)

The Pennsylvania Department of Environmental Protection (DEP) has undertaken a path to build "high performance green" buildings as part of the objectives of the Governor's Green Government Council. The first building, completed in 1998, is used as the DEP's regional headquarters in Harrisburg. The Cambria office, located in Ebensburg, is DEP's second building. Many of the lessons learned from the first building were successfully applied to this building, which was completed in 2000. The objective was to provide a comfortable and productive work environment while minimizing its short- and long-term environmental impacts.

This report covers an energy analysis performed by the High Performance Buildings Research group from the National Renewable Energy Laboratory (NREL) in Golden, Colorado. The study included a detailed review of the energy systems, analysis of the 15-minute power data from July 2001 to February 2002, and review of the utility bills. Daylighting measurements were also conducted during the site visit in July 2001.

14. SUBJECT TERMS

Cambria Office Building; high performance buildings; Pennsylvania Department of Environmental Protection; green buildings; building energy analysis
15. NUMBER OF PAGES

16. PRICE CODE

20. LIMITATION OF ABSTRACT

OF THIS PAGE

Unclassified
19. SECURITY CLASSIFICATION OF ABSTRACT Unclassified
UL 